\title{
Embracing Creative Transience: From Political Remix Video to Digital Collage
}

\author{
DIRAN LYONS \\ Assistant Professor, Porterville College
}

\section{ABSTRACT}

In this essay, I explore my latest series of digital collages titled Notes and Narratives. These works utilize additive, subtractive, and substitutive remix strategies to integrate Gothic, Renaissance, and Baroque paintings with visages of Donald Trump and his associates. The series appropriates historical masterworks to interrelate the theologico-political foundations of the original paintings with the political turbulence experienced under the Trump administration.

Notes and Narratives foregrounds remix as a powerful and potent tool for disruption, change, and communication in the continuum of pedagogic praxes and remix studies. My previous artistic work was dedicated to creating political remix videos, and this body of work represents a fork in my creative practice. The immediacy of the collages draws upon intertextuality and remix strategies to reveal passionate polemical positions, positing contentious criticisms of the political leadership in the United States.

\section{INTRODUCTION}

I encountered Jorge Luis Borges's short story "The Garden of Forking Paths" for the first time in 2003, while pursuing graduate studies in the Department of Art at the University of California, Santa Barbara. Borges's ideas were routinely integrated into discussions about interactive digital media, video art, and film studies. Many of the UCSB faculty shared a scholarly fascination with, if not fervent commitment to, a philosophical lexicon derived from thinkers like Leibniz, Nietzsche, and Deleuze that explores a reverberant interconnectivity of time, events, and the immanence of creative potential. Borges's "The Garden of Forking Paths" fits seamlessly into these frameworks.

The line in the story that maintains an inescapable grip upon me-verily, still gives me chills each time I read it - occurs in the closing moments: "Time forks perpetually toward innumerable futures. In one of them I am your enemy."1 Not in only one of them, I fear. In our contemporary era, the devastating effects of war permeate the regions of Afghanistan, Iraq, Libya, Syria, and elsewhere. Relations between the United States and Iran, China, North Korea, and Russia are tenuous. Ours is an historical moment riddled with war: global warfare, currency wars, class wars, race wars, religious wars. To paraphrase an influential voice: The last days will be filled with wars and rumors 
of wars. ${ }^{2}$ An embittered $19^{\text {th }}$-century philosopher fortified his pessimism by quoting Lord Tennyson's phrase, "Nature, red in tooth and claw." 3 As an artist, my projects accept this aspect of life and are confrontational, focused on social strife, and aim to function as a battle response.

The UCSB Department of Art was a stone's throw away from the breathtaking natural beauty of the Pacific Ocean, situated within a larger community of extraordinary wealth and prosperity, but fellow classmates and professors alike would convene in local cafés and pubs with a burden to debate how to create a better world. Many of us knew we were merely passing through this idyllic place, while a foreboding world of war, poverty, racism, oppression, and injustice required attention. We contemplated the role of art in making possible worlds not only theoretical, but actual.

Even before arriving in Santa Barbara, my creative efforts consistently gravitated toward the political. This was due largely to the rigorous instruction of Charles Gaines at California State University, Fresno in the late 1990s. As a result of his teaching, my favorite modern artworks were works of protest: Goya's The Third of May 1808, Manet's Olympia, Picasso's Guernica, Duchamp's L.H.O.O.Q., and the collages of John Heartfield. My favorite contemporary artists were all politically outspoken as well: Marina Abramović, Joseph Beuys, Hans Haacke, Barbara Kruger, Daniel J. Martinez, Marko Peljhan, Cindy Sherman, Kara Walker, and many others. I wanted to participate in that rich tradition, to create art as an act of resistance. My projects took on the diverse forms of painting, photography, performance, installation, and video art and considered different effects of corporate capitalism on media messaging, mental health, civil rights, and the environment.

My graduation from UCSB in 2004 synchronized with remarkable changes in societal communication via the onset of the blogosphere and social media spaces like Facebook, Myspace, and YouTube. At that time, I recognized the value in transitioning from a studio practice focused on gallery and museum exhibition to the new milieu of immediate distribution on YouTube. For two years, I consumed as many political remix videos (PRVs) ${ }^{4}$ as I could, for I was fascinated by the form's ability to recalibrate audiovisual sources in order to repudiate the ideologies embedded within them. Through the PRV, the artist holds a corrective lens to the postures initially propagated by mainstream media, Hollywood, and other powerful institutions.

My first foray into political remix practice was George W. Bush Battles Jesus Christ (2007), ${ }^{5}$ a reply to Jonathan McIntosh's call for PRVs to screen at the University of Southern California in February of 2008. I found remix video so captivating that, soon thereafter, I all but abandoned ${ }^{6}$ working three-dimensionally and committed my creative energy to completing 60 PRVs from 2007-2017. I addressed issues of personal import, from the topical to the historical, including responses to the rhetoric of George W. Bush and Barack Obama, war and oil, racism and genocide, US military conflicts and economic policy, and finally, the ongoing discussions of US Civil War memory and Confederate monuments, challenging primarily southern revisionist efforts that attempt to rebrand the conflict as one over states' rights and not as a feud over chattel slavery. ${ }^{7}$

The election of Donald J. Trump challenged me to discard my previous methodologies. Trump utilizes a style of speech that undermines the strategies I employed to criticize former figureheads. Over the 10-year span, I produced several remixes classified as "identity corrections," reorganize words from political speeches in order to form new statements that destabilize the speaker's actual position. Examples of this type of work include my re-creation of Chris Morris's 2003 Bushwhacked II $^{9}$ (a low definition identity correction of George W Bush's 2003 State of the 
Union address that I remade from scratch using high quality sources) and State of the Union $2014^{10}$ which remixes Obama in a similar fashion. PRVs of this order can be highly entertaining, as they often incorporate humor through exaggeration. The use of exaggeration in these works provides an important clue that the remix is satirical. I discarded many attempted identity corrections of Trump, as his actual rhetoric is already outrageous or hyperbolic. Statements such as "(I) Grab (women) by the pussy," "11 and "I could stand in the middle of 5th Ave and shoot somebody, and I wouldn't lose any voters," 12 attest to his egregious use of the outrageous and hyperbolic, respectively. In my remix practice, I began contemplating different strategies that might more effectively interrogate Trump's antics in discourse.

From 2016-2019, I taught an art theory class at CSU Fresno entitled "Ideas of Visual Culture: Art, Media, and the Computer." With my students, I re-read John Berger's Ways of Seeing (1972) and watched his TV series by the same title. In the text, Berger states that "a film unfolds in time, and a painting does not." 13 He goes on to note that "in a painting, all its elements are there simultaneously." 14 In the TV series, Berger adds that "paintings lend themselves to easy manipulation. They can be used to make arguments or points which may be very different from their original meaning." 15 I became transfixed by these statements, and the images he examined suddenly invited creative reworking.

\section{REMIX STRATEGIES: ADDITION, SUBTRACTION, SUBSTITUTION}

I started a series of digital collages in 2019, utilizing additive, subtractive, and substitutive remix strategies to integrate Gothic, Renaissance, and Baroque paintings with the visages of Trump and an assortment of other characters. Old masterworks provide fertile soil for conceptual interrelationships between the theologico-political foundations of the original paintings and the political turbulence under the Trump administration. My task, ultimately, is to highlight that this new offshoot in my practice still foregrounds remix as a powerful and potent tool for disruption, change, and communication in the continuum of pedagogic praxes and remix studies.

The fair use doctrine in the US copyright code requires derivative works to be transformative, but the language in Title 17 Section 107 of said code fails to legally define transformation. When I create derivative works, my aim is to modify media fragments such that their original meanings recede and new meanings come to the fore. This, in my estimation, is transformation: acting upon one thing and causing it to become another. To be clear, this understanding does not deny the intertextual nature of derivative works. Rather, it is an acknowledgment that the new work must retain a semblance of its appropriated features, while expressing something quite different and new through the intentional combinatory effort of the artist. In what follows, I deliberately select more subtle historical precedents that employ minimal intervention on the part of the artist. In their light, I look at strategies that I borrow from them to arrive at my own acts of transformation. 

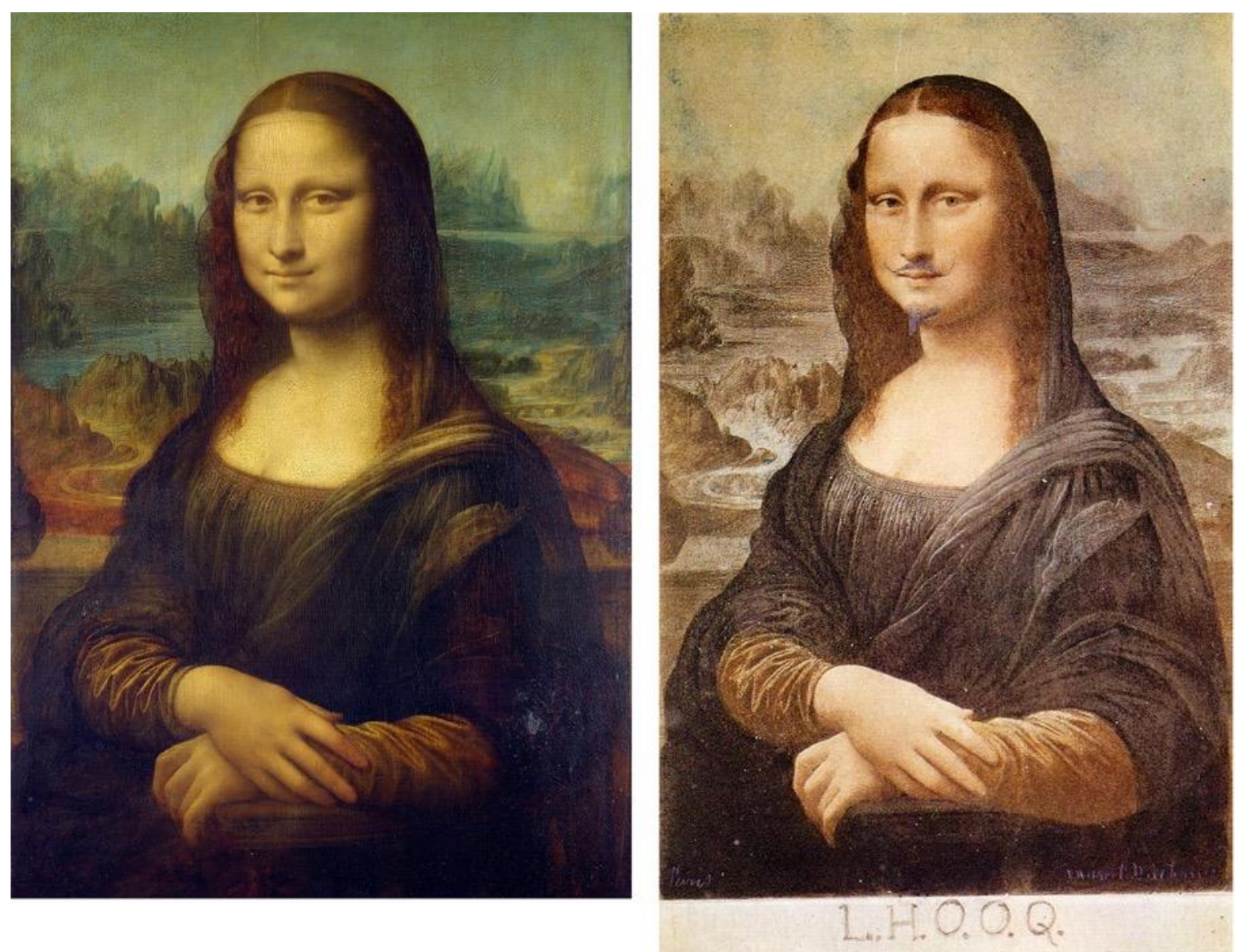

Figure 1 (left). Leonardo da Vinci, Mona Lisa (1503-1506). Oil on panel.

The Louvre Museum, Paris, France. Public domain.

\section{Figure 2 (right). Marcel Duchamp, L.H.O.O.Q. (1919). Pencil on card. Philadelphia Museum of Art, Philadelphia, PA, USA. Public domain.}

When one source is added to another, the composite encourages the consideration of the relationship between the two (or more) synthesized components. ${ }^{16}$ The commingled elements become a sum of their parts, enabling a new commentary to emerge which re-examines the source materials and/or advances a separate issue through the fusion. When Marcel Duchamp drew a mustache on Leonardo da Vinci's Mona Lisa, he raised questions about art history, representation, gender, and the privileged male gaze. ${ }^{17}$ With just a few pencil marks, the new work signified something else. Similarly, additive processes can be powerful in remix video as well. With Jeremiah Wright Painting a Picture of US Aggression (2008), ${ }^{18}$ I responded to the media's nearly unanimous condemnation of Barack Obama's pastor by simply adding footage that reflected Wright's contentious assertions from the pulpit. Wright's passionate tirade — coupled with the clips I selected to illustrate it - registers on emotional and visceral levels, while simultaneously making the brutality of US military intervention more palpable. Although the work is highly illustrative, my intent in using commercial and Hollywood footage is not merely to achieve a visual redundancy or instantiation ${ }^{19}$ of the historical events Wright describes. Rather, the use of Terminator 2 at the 
climax of the video, for example, forewarns of a disastrous potential future as a repercussion of US military aggression. Jonathan McIntosh screened the video at Ars Electronica in Linz, Austria as part of the 2008 New Cultural Economy Symposium, attesting to the value of such additive strategies. The assembled audience there, hailing from locations all over the world, responded with applause. ${ }^{20}$ This collective reaction stood in stark contrast to the US mainstream media's unfavorable framing of Wright, which ultimately led to Obama's denunciation of his former pastor. $^{21}$
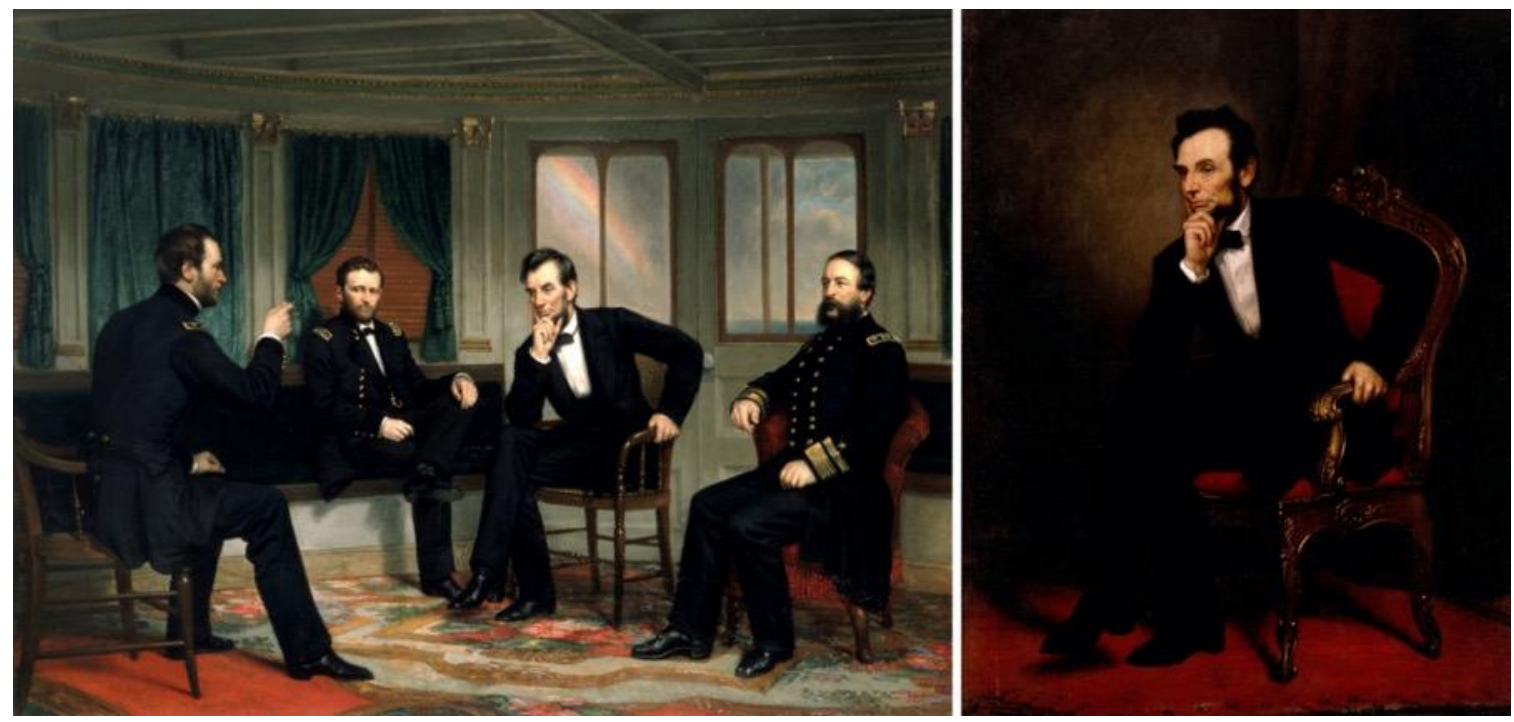

Figure 3 (left). George Peter Alexander Healy, The Peacemakers (1868). Oil on canvas. Collection of the White House, Washington, District of Columbia, United States of America.

\section{Figure 4 (right). George Peter Alexander Healy, Abraham Lincoln (1869). Oil on canvas. Collection of the White House, Washington, District of Columbia, United States of America.}

Conversely, with a subtractive approach, ${ }^{22}$ an artist distills a source to specific elements to change their signification. By eliminating certain features, one can highlight ideas through the components that remain. In the paintings of $19^{\text {th }}$-century American portrait painter George Peter Alexander Healy, specifically The Peacemakers (1868) and Lincoln (1869), the rendering of Lincoln is quite similar. The former provides a glimpse into the historic meeting of Lincoln's high command just two weeks prior to Robert E. Lee's surrender at Appomattox Court House on April 9, 1865. When Healy removes the generals in 1869, a viewer can freely contemplate any issue related to Lincoln's legacy.

This type of simplification correlates to supercut remix videos, which feature tedious compilations of a specific word, phrase, behavior, or cliché from a variety of sources. I have enjoyed using the supercut form for its ability to offer political observations or highlight issues in media that may go unnoticed in casual viewing. In Obama Likes Spending (2011), ${ }^{23}$ I surveyed the White House video archive to assemble every time Obama said "spend," "spending," or "spent" during his first three years in office. The video featured over 600 examples, and through this distillation I intended to raise questions about fiscal responsibility and the United States' ballooning national debt. The 
remix drew the attention of Andy Baio, who coined the term "supercut." In his Wired article, "The Video Remix 'Supercut' Comes of Age," 24 Baio argues that the rigor of a supercut helps to strengthen the effectiveness of its message. He screened the video the following year at ROFLcon 2012 at the Massachusetts Institute of Technology, contending that supercuts of this order may have the potential to influence elections. ${ }^{25}$ In 2015, I turned my attention to then presidential candidate Donald Trump. The Hollywood Reporter ${ }^{26}$ Vanity Fair ${ }^{27}$ and a handful of other sites wrote about my $\underline{\text { Trump Vs Mexico Supercut }},{ }^{28}$ but despite my hopes for a wide reach it garnered only 24,000 views. Nevertheless, the remix underscored a strategic divisiveness from the onset of Trump's campaign.
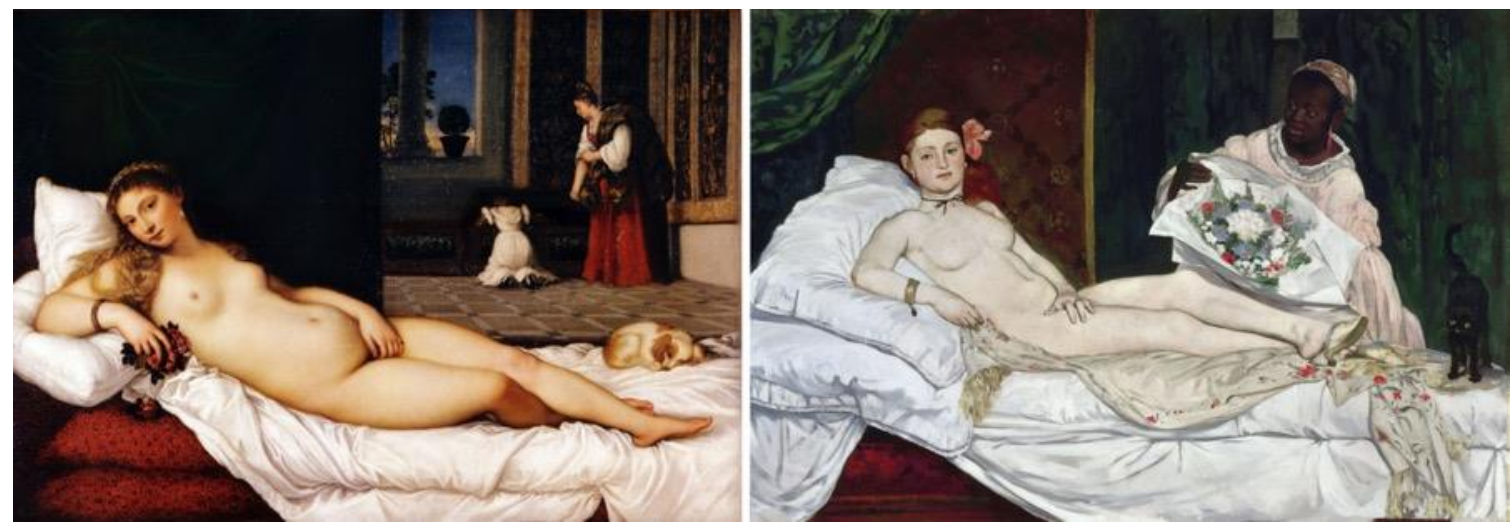

Figure 5 (left). Titian, Venus of Urbino (1534). Oil on canvas. Galleria degli Uffizi, Florence, Italy. Public domain.

\section{Figure 6 (right). Édouard Manet, Olympia (1863). Oil on canvas. Musée d'Orsay, Paris, France. Public domain.}

Lastly, in the case of substitution, one source serves as a ground for addition and subtraction ${ }^{29}$ simultaneously. ${ }^{30}$ Édouard Manet's response to Titian's Venus of Urbino (1538) is a preeminent example. In Manet's Olympia (1863), the artist challenges the expectations of male viewership by replacing important signifiers: the company featured in the room, the confident and uninviting expression on Olympia's face, and her stern left hand which impedes male fantasy. ${ }^{31}$ Manet exchanges a frightened black cat for Titian's restful dog, possibly alluding to the dangers of the sordid transaction the implicated male spectator intends to indulge in. ${ }^{32}$ Ultimately, this new arrangement of details delivers a formidable critique of power relations in mid-19 ${ }^{\text {th }}$-century France.

My political remix videos also utilize tactics of substitution. In Presidential Debate (Anchorman Remix),${ }^{33}$ for example, I removed the original audio of the first Clinton-Trump debate and applied petty, hubristic, and misogynist statements from Anchorman to the candidates' lip movements. The remix lamented the overall depreciating quality of the election cycle discourse, largely a result of Trump's unprecedented lack of decorum. I sent the remix to writers in the media, hoping that its exposure through mainstream articles would generate further debate on the embarrassing nature of Trump's rhetoric. Although no media reviewed it, the video got downloaded from my YouTube channel and re-uploaded multiple times to Facebook, where in aggregate it totaled around $\underline{20}$ million views. The comment sections contained spirited deliberation on the choice before the United States electorate. 
My final effort of the season, The 2016 Election Gets Princess Brided,${ }^{34}$ meshed the cult movie with unsettling moments from Trump's campaign. Despite its clear aversion to the newly elected $45^{\text {th }}$ president of the United States, only Ben Shapiro's right-wing news and opinion site The Daily Wire wrote about the video.$^{35}$ Liberal media had helped promote my work in the past, most notably 99 Problems (Explicit Political Remix). ${ }^{36}$ Due to this apparent declining enthusiasm in the media for my videos and because it takes months to create them, I embraced a creative shift in the form of digital collage. Collage retains the recalibration tactics described above while communicating with a compelling type of immediacy. This is advantageous given the rapid pace of mainstream media and news cycles today.

\section{NOTES AND NARRATIVES SERIES: NEW COLLAGE WORKS}

I refer to my collage work from 2019 to the present as the Notes and Narratives series. While the collages combine images from art history with topical politics, their text component meditates on colloquial phraseology or tongue-in-cheek statements composed of letters I extract from popular magazines and corporate advertising. The letters congeal in a format reminiscent of the ransom note, itself a document of recycled materials used to make demands or threaten one's adversaries. Like my PRVs, the collages reveal polemical positions, positing contentious criticisms of Trump and his base.

With these collages, I aim for the main postures of the work to be accessible to a general audience. This does not mean the series neglects the academic and theoretical paragons of post-structuralism, deconstruction, and semiotics. Friedrich Nietzsche, Ferdinand de Saussure, Charles Sanders Peirce, Roman Jakobson, Ludwig Wittgenstein, Roland Barthes, Jacques Derrida, Umberto Eco, and others address the diverse roles, power, and consequences of language and images. The study of their scholarly literature enriches the creative process of reworking extant cultural materials.

Although the focus of this section is primarily the collages themselves and not an investigation into semiotic theory, a brief synopsis of such theoretical frameworks is still in order. Regarding the elusive and diverse character of meaning, Eco used the term "unlimited semiosis" ${ }^{37}$ to refer to the unrestrained transference of meaning from one signifier ${ }^{38}$ to another signifier, to yet another, ad infinitum, all under the aegis of connotation ${ }^{39}$ (a term Barthes uses to refer to how a diverse range of contexts inform the meanings of an image for the subjective spectator). ${ }^{40}$ In other words, a sign ${ }^{41}$ so unshackled will constantly receive its meaning through other signs in an endless chain of signification, until denotation ${ }^{42}$ attempts to artificially stabilize it again. (Within this dichotomy, the denotative meaning of a rose, for example, is that it is a flower, while the connotative meaning can refer to a wider range of ideas, including purity, friendship, love, etc., depending on the flower's color and other factors.) This phenomenon deeply complicates interpretation in general.

Building a great deal on Barthes (but also on Nietzsche), Derrida is best known for developing methodologies of "deconstruction." " Although not exclusively limited to the analysis of language, deconstruction usually involves scrutinizing a written text in order to discover a prevailing metaphor ${ }^{44}$ or grounding system. In so doing, a critical interrogation of the text ultimately exposes unfounded presuppositions that the text depends on to uphold its coherence. (Such presuppositions usually involve the arbitrary privileging ${ }^{45}$ of one term over another within a binary opposition. $)^{46}$ The resulting revelation is that the text relies on a fallacious argument or is self-refuting. 
Deconstruction contends that this condition is absolutely germane to language. ${ }^{47}$ Consequently, the idea of an a priori grounding truth is spurious, and in fact all argumentation will rely on a dominant metaphor that masquerades as natural, axiomatic, and unquestionable.

If I accept these theoretical formulations themselves as natural, axiomatic, and unquestionable, even my most fervent attempts to clearly communicate the intentions behind my work will always be encumbered. This is an unavoidable reality of polemical delivery. However, the utilization of polemic through remix and other media can inspire spirited dialogue, which as a corollary has the potential to stimulate the enhancement of culture. While acknowledging that the interpretations of the works that follow and my political contentions that motivate them will not resonate with all readers, I echo Jean-François Lyotard in affirming that ideological consensus ${ }^{48}$ and homogenization are not my ultimate goals. The point I emphasize is that, by expressing my convictions, I attempt to confront an audience on some of the difficult questions of the day. In turn, receiving critical feedback helps me refine my thinking and modes of communication. Challenging established language games, ${ }^{49}$ not homogeny, is the goal.

The role and restrictions of the artist within larger societal frameworks and the weight images carry are addressed in Barthes's works, Camera Lucida and Writing Degree Zero. He asserts that a message always carries its opposition regardless of intention. ${ }^{50}$ This means that even if one creates a work of art with ideas and theories in mind, the objective result is pregnant with signs that rebut or call into question the initial iteration. My first collage attempted to interact with these types of ideas through the combination of analog and digital materials. I located a found photograph of Trump, output it in black and white with a Xerox printer, and then tore out a rectangular cross section from the image, creating a blank horizontal path for the placement of a phrase. The empty segment traversed Trump's portrait, blocking his vision, like a blindfold. I then scanned the mangled print for further digital manipulation, proceeding to piece together individual letters from downloaded magazine covers. With this type, I formed the statement, "I recommend this candidate with no qualifications whatsoever."

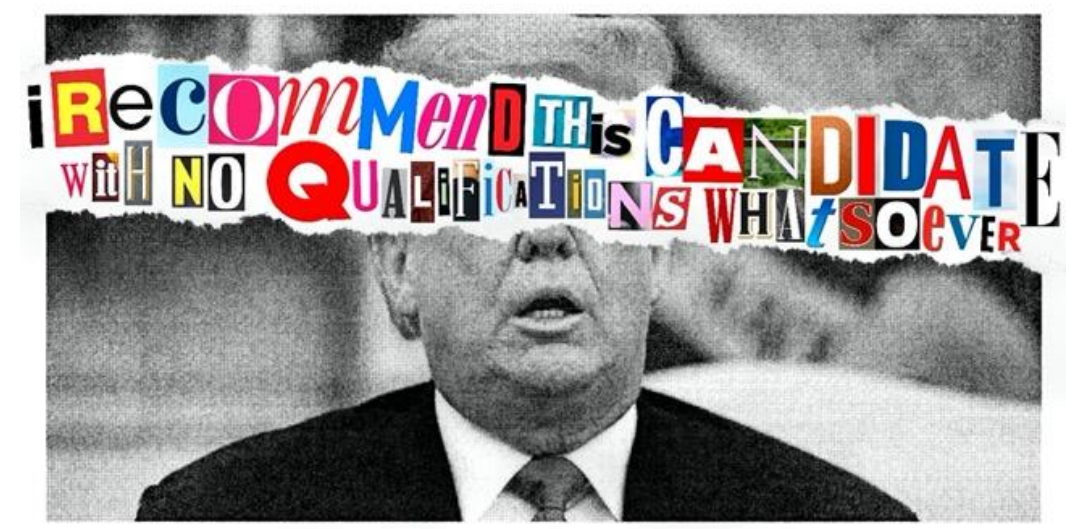

\section{Figure 7. Diran Lyons, I Recommend This Candidate with No Qualifications Whatsoever (2019). Kodak digital print. Courtesy of the artist.}

This text component has a built-in ambivalence, or a type of conceptually dichotomous vibration. ${ }^{51}$ At first, the statement appears as an endorsement. Upon further contemplation - particularly when conjoined with the unflattering image I selected-it conveys a negative sentiment 
about Trump in an innocuous manner. I completed three more works with this methodology in 2019, using the texts, "I cannot say enough good things about him," 52 "No person would be better for the job," 53 and "CTRL+ALT+DEL,"
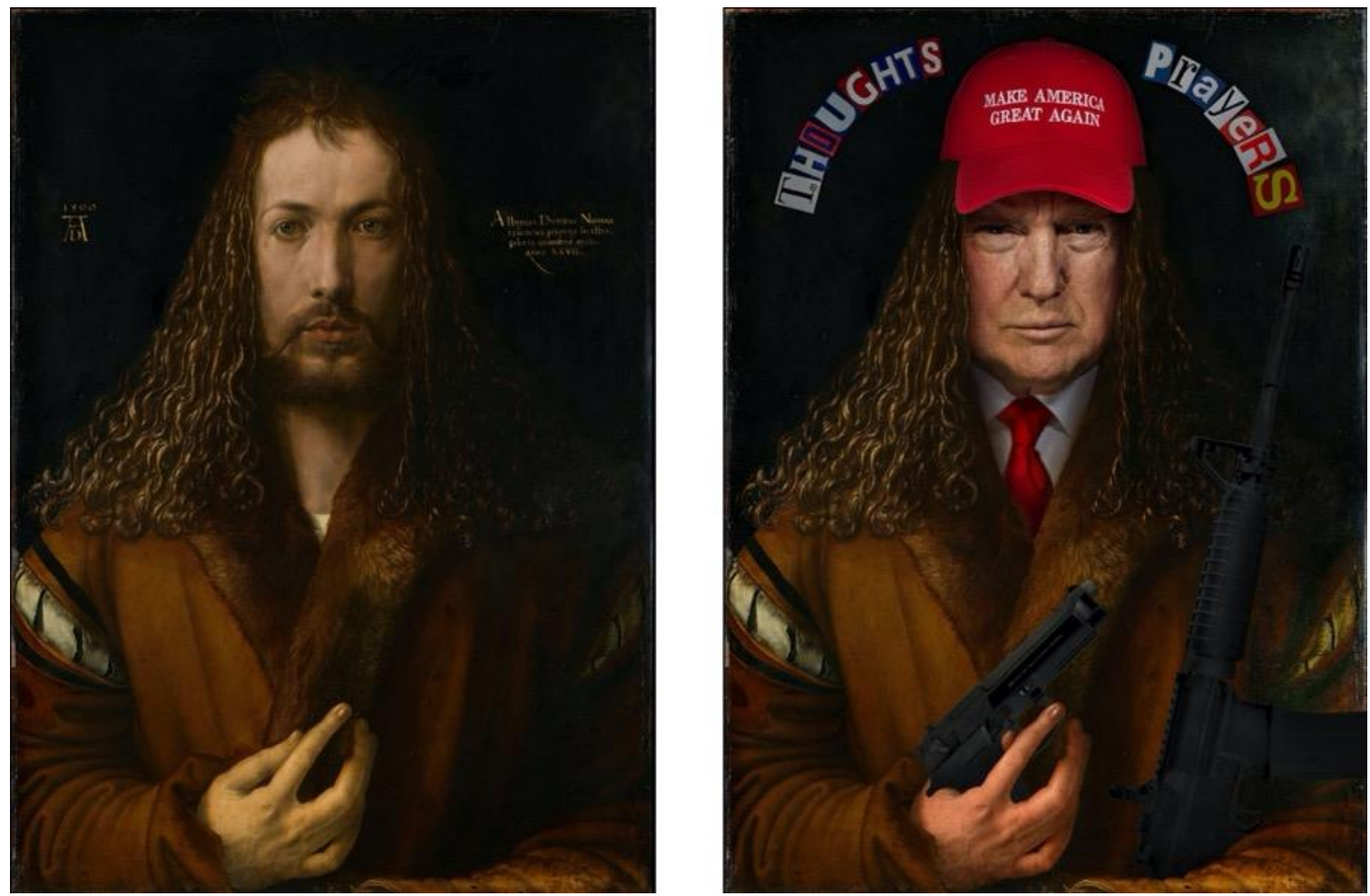

\section{Figure 8 (left). Albrecht Dürer, Self-Portrait at Twenty-Eight (1500). Oil on panel. Alte Pinakothek, Munich, Germany. Public domain.}

\section{Figure 9 (right). Diran Lyons, Thoughts and Prayers: Re-Imagining Albrecht Dürer's Self- Portrait at Twenty-Eight (1500) (2019). Kodak digital print. Courtesy of the artist.}

The next collages turned to Renaissance masterworks to expand on their messaging. The German painter Albrecht Dürer possessed creative facilities so powerful that art historians refer to him as "the Leonardo of the North." 55 His self-portrait from 1500 is Renaissance portrait painting par excellence: a delicate depiction of his long and curling hair juxtaposed with an intense and captivating straightforward gaze. This specific pose is almost exclusively reserved for Christ. ${ }^{56}$ Here, Dürer offers the viewer a new Vera icon: the artist as the Word of the living God and Creator of the world. The New Testament foregrounds Christ's centrality to creation in John 1:1-3:

1 In the beginning was the Word, and the Word was with God, and the Word was God.

2 The same was in the beginning with God.

3 All things were made by him; and without him was not any thing made that was made.

This ambitious visage is neither an expression of vanity nor delusion. ${ }^{57}$ Rather, the artist relies on an intertextual connection to the scripture above to announce the role of the artist as an advocate of 
the individual, a humanist ${ }^{58}$ view that eventually led to the Enlightenment. Dürer posits himself as "a creator," wielding the same power God has: to create! He assumes this role not as an act of immense egotism, but to celebrate and showcase his agency. The creative genius is at work and is divinely inspired. ${ }^{59}$

In my modification of the theme, Trump's face covers Dürer's. Whereas Dürer represented the divine spark indwelling in the genius artist, I position Trump as a surrogate for Christ, ${ }^{60}$ appearing as a long-haired hunter from the set of Duck Dynasty after a fresh shave. The right-wing reverence for the Second Amendment and gun ownership is evident. Trump's right hand, which religious icons reserved for signs of blessing, ${ }^{61}$ grasps a military grade Beretta M9, the official semiautomatic pistol of the United States Armed Forces. ${ }^{62}$ Resting upon Trump's left shoulder is a smoldering assault rifle, its smoke rising into recycled text that frames Trump's portrait like a halo: "Thoughts" and "Prayers." Regardless of the increasing frequency of mass shootings in the United States, the bereaved must somehow find solace with these words alone, for gun control legislation is consistently declared by conservatives to be an affront to US values. While the blessings of gun ownership and ready access to assault weaponry remained safe under Trump's presidency, his antiimmigrant rhetoric appears to have inspired attacks like Patrick Crusius's 2019 mass shooting that killed 23 people and injured 23 others in El Paso. ${ }^{63}$ Also troubling was Trump's repeated references to the US Civil War, ${ }^{64}$ eliciting multiple public assemblies of armed homegrown US militias during the course of Trump's four years in office. ${ }^{65}$ The official Twitter account of the Republican Party of Arizona asked Trump supporters whether they would lay down their lives to see to the overturn of Trump's 2020 election loss. ${ }^{66}$ In November of 2019, shortly after disseminating invites for the first public showing of my collage series, I experienced a sobering sense of these violent proclivities in the form of an anonymous death threat if the gallery followed through with the exhibition. If Dürer deified the artist as a mouthpiece of God, Trump deified violence, intimidation, and bullying in the pursuit of maintaining power. ${ }^{67}$

\section{RESPONSES TO WHITE SUPREMACY AND THE COVID-19 PANDEMIC}

Two of my collages in 2019 built upon the last two remix videos I had made the previous year. The first video, What If Trump Talked About White Terrorists Like This? ${ }^{68}$ scrutinized Donald Trump's rhetoric on white criminals. I took statements Trump made about non-white terrorists and applied them to news footage of whites who committed acts of terror. ${ }^{69}$ The result is a portrayal of Trump consistent with his position that designating individuals as terrorists is of paramount import. (Recall his relentless insistence that Obama use the terminology "radical Islamic terrorism,"70 yet Trump failed at every opportunity to apply the terrorist label to white mass murderers operating with political motivation.) Reminding the viewer of Trump's admitted disdain for political correctness, the remix implores us to contemplate why he reserves his vitriol only for non-whites, while never condemning white terrorists in the manner constructed by the remix. As such, the video exploits Trump's language to reveal an indisputable white privilege operating within it. I investigate how Trump's rhetoric manipulated a large contingent of his base in the following reworking of a Renaissance painting by Flemish artist Hugo van der Goes: 


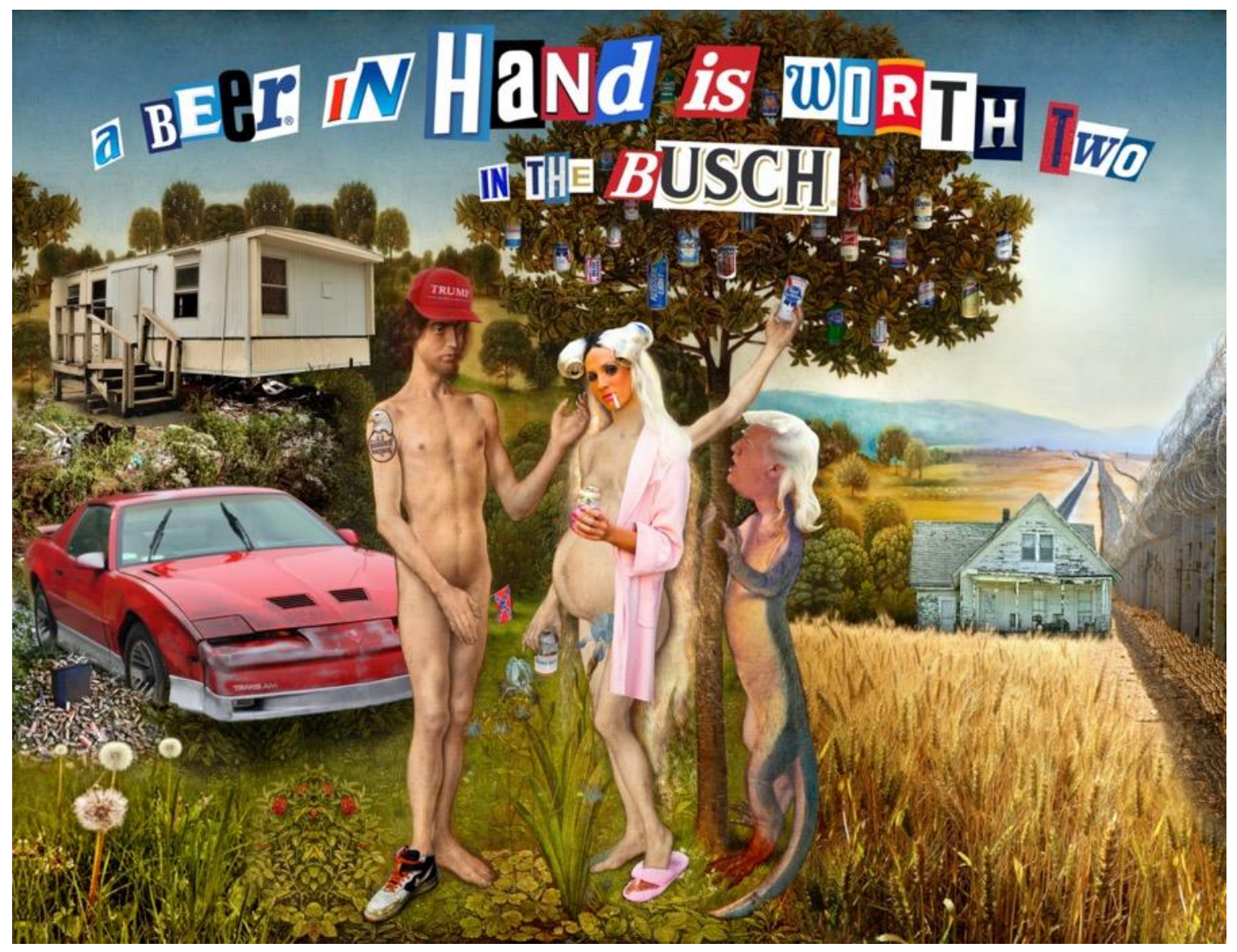

\section{Figure 10. Diran Lyons, Re-Imagining Hugo van der Goes's The Fall of Adam (c. 1479) (2019). Kodak digital print. Courtesy of the artist.}

In Abrahamic traditions, the primordial couple, Adam and Eve, encounters a serpent in the paradisal Garden of Eden. ${ }^{71}$ Hugo van der Goes's The Fall of Adam (1475) interacts with the scriptural account in a way unique to the Renaissance: the serpent stands upright. I first saw this work in my undergraduate art history studies and had a strong fascination with its biblical attentiveness. When the serpent succeeds in seducing the first humans into eating the forbidden fruit, ${ }^{72}$ the Lord God punishes the serpent with two curses, one of which entailed the following penalty: "You will crawl on your belly, and you will eat dust all the days of your life." ${ }^{73}$ The implication, of course, is that before this event the serpent had not been compelled to slither upon the ground.

I began the collage by addressing the central figure of Eve, using my favorite image result from the search terms "poor," "white," "trash," and "woman." Her bleached blonde hair envelops beer cans for decoration, and this set me on an adventure for the cheapest canned beer images on the internet. I positioned an assortment of these where apples once hung in the tree overhead. Instead of the knowledge of good and evil ${ }^{74}$ the tree now dispenses an endless supply of low-cost rice beers, which Adam and Eve seemingly use to anesthetize their suffering, even while Eve is pregnant. Although their economic reality has not changed a great deal since 2016, the man wears a "Keep America Great 2020" mesh hat, sports a "US Border patrol" tattoo, and holds a mini confederate 
flag in hand. To the left, a downtrodden red Trans Am has seen better days, and there appears to be an overall acceptance of a life mired in squalor. The stage is set for Trump-portrayed with a blonde mullet reminiscent of 1980s fashion - to make his appearance as the walking and talking serpent.

In his 1967 essay, "The Death of the Author," Barthes argues that the meaning of a cultural artifact is contingent upon the cultural and political predispositions of the individual who consumes it. ${ }^{75}$ In this estimation, a work's connotations are negotiable and never dictated by the objectives of its creator. As such, one hundred viewers might examine the collage at hand and give unique interpretations that differ from the following diegesis, in which I recount my digestion of issues and events that inspired the work. From its onset, I recalled the deceptive pitch of the serpent that, through exaggeration, misrepresentation, and false promises, resulted in the first humans' downfall. ${ }^{76}$ With Trump now cast in the role of the deceiver, I imagined what he might offer his interlocutors. In alignment with his campaign, he likely begins by ridiculing illegal immigrants, which he reductively represents as drug dealers, criminals, and rapists. ${ }^{77}$ After he preys on the couple's fears of "the other," he echoes the familiar humanist romance with the great individual, assuring them that only he can improve their plight, keep them safe, defeat ISIS, fix the election system, ${ }^{78}$ reopen the economy ${ }^{79}$ pay down the national debt, ${ }^{80}$ and so forth. Perhaps the most misleading statement is this: because they share a mutual European ancestry, he will operate with their best interests in mind. In so doing, he attempts to dissuade them from partnering with liberation movements of all races, committed to mass civil disobedience and non-cooperation. Trump knows that if they turn their frustration onto the corporate state, they will unmask and identify the true sources of their oppression. He therefore blames the couple's pain on undocumented workers, Muslims, African Americans, and others. ${ }^{81}$ Unfortunately, it works.

As I recalled an assignment Charles Gaines gave in his Content and Form class at Fresno State in 1998, the collages start to incorporate colloquial phrases at this point. For the assignment, Gaines invited the class to contemplate the conceptual underpinnings of metonymy, which Roman Jakobson and others investigated. Jakobson maintains that the linguistic character of the metonym operates by selection and substitution. ${ }^{82}$ Derrida contends that metonyms are figures that "substitute part for whole, or which evoke some object by signaling out a salient detail or aspect of it." 83 The phrase "All hands on deck" or a flag for a nation are straightforward references to this distinction. The former substitutes a body part for an entire person, while the latter uses a design to reference a whole culture. It is via substitution - the system of exchange in the elusive relation between signifier and signified - that metonymy propels multifarious ideas behind the veil of representation. ${ }^{84}$ By including a cultural idiom, I contextualize the imagery by referencing an idea without directly or literally asserting it.

At the top of the composition, I collected letters from inexpensive beer signage to form the phrase "A beer in hand is worth two in the Busch." This is a ludic word play on the phrase, "A bird in hand is worth two in the bush," which cautions against taking unnecessary risks that make one vulnerable to great loss. The US electorate took precisely this type of gamble in 2016 by electing Donald Trump. Trump's lack of experience in politics was a point of contention from the beginning of his 2016 campaign. Although one cannot picture with certainty the condition of the United States after four years of a Hillary Clinton administration, her extensive track record as a public servant was well known. In this light, she was the proverbial "bird in hand." After a series of mismanaged crises, most notably the COVID-19 pandemic $^{85}$ which saw the deaths of over 341,000 Americans $^{86}$ 
by the end of 2020, the colloquialism invites speculation on time, decision, and the persistent whatifs that may occupy reflection on contemporary US history for a long time to come.

I will now briefly turn to the second remix video I made in 2018 , which reminded me of my adolescence. When Ken Burns's The Civil War premiered in 1990, my father invited me to watch it with him. I asked what the conflict was about, and he immediately said "slavery." Burns, too, said the same in an interview ${ }^{87}$ about the restored, high-definition version of the series released in 2015. With that remastered footage, I created Shelby Foote on the Monuments Men: ${ }^{88}$ a highlight reel of Foote venerating southern generals. With a drive to remove Confederate monuments well underway 30 years later, the remix showcases the problematic nature of Foote's comments. They overlook the Confederate cause as an expression of white supremacy, while proffering ahistorical sentiments steeped in "Lost Cause" 89 mythology. These sentiments still thrive, as Trump's presidency repeatedly made evident. On the evening of August 11, 2017, with shades of a Ku Klux Klan gathering, white supremacists protested the proposed removal of the Robert E. Lee monument in Emancipation Park in Charlottesville, Virginia. With a sea of Tiki torches blazing against the night sky, the crowd surrounded the statue of Thomas Jefferson at the University of Virginia, shouting, "White lives matter!" and various anti-Semitic epithets. The next day, James Alex Fields murdered Heather Heyer and injured 19 others by driving his Dodge Challenger into a crowd of anti-hate demonstrators. When pressed to condemn this incident, Trump did so, but still maintained that there were fine people on both sides of the protests. ${ }^{90} \mathrm{He}$ argued for preserving the monuments of Robert E. Lee and other Confederate generals, asserting that the US should remember its history, not destroy it. Confederate statues continued to receive Trump's unwavering support. During 2020 protests against monuments and military bases named for Confederate leadership, Trump again came to their defense. In response, The Lincoln Project ${ }^{91}$ issued a statement, calling him the second president of the Confederacy. ${ }^{92}$

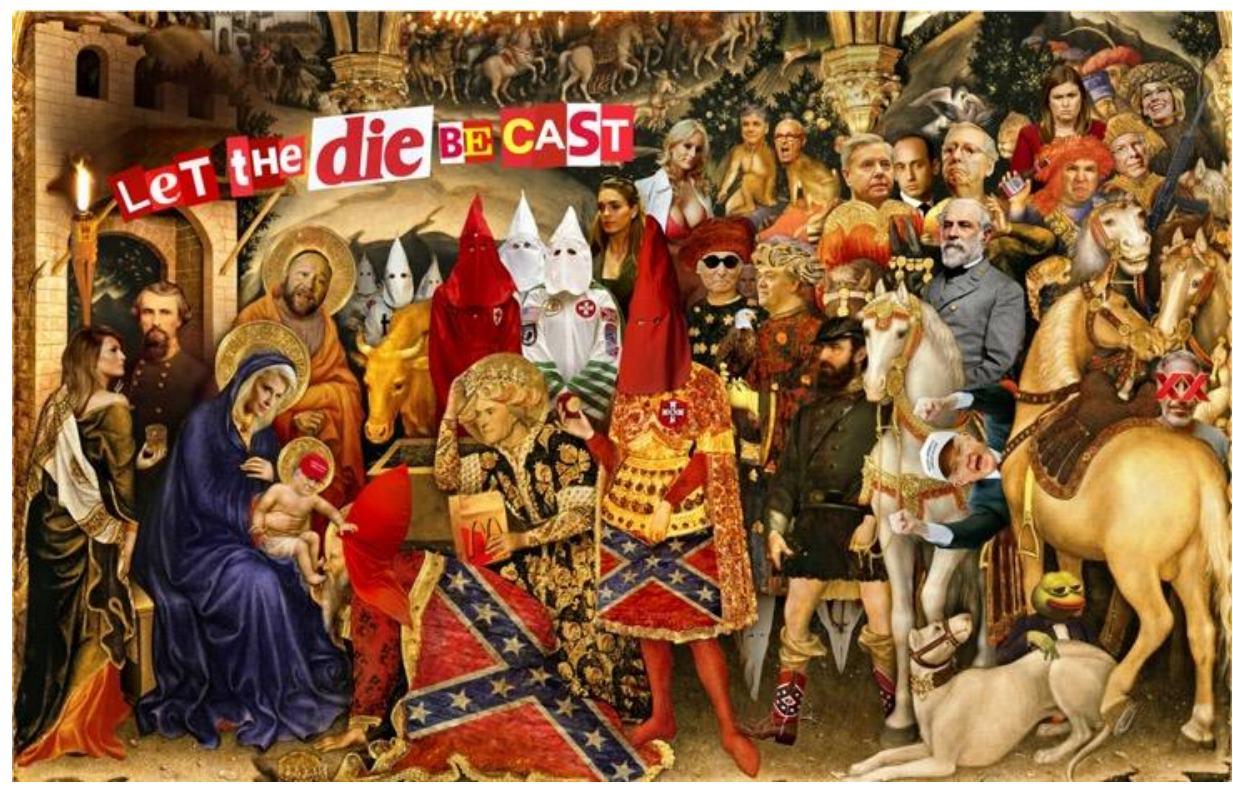

Figure 11. Diran Lyons, Adoration of the MAGA Clan: Re-imagining Gentile da Fabriano's Adoration of the Magi (1423) (2019). Kodak digital print. Courtesy of the artist. 
For the next digital collage, I looked to iconic altarpieces that contain vast reserves of space. This enabled me to combine a host of historical and contemporary characters. In the late International Gothic period, Gentile da Fabriano's notable nativity scene, The Adoration of the Magi (1423), provides an extensive crowd in the artist's fantastical interpretation of an account in the book of Matthew. The story describes the magi, or wise men, who travel to Bethlehem to offer gold, frankincense, and myrrh, and to worship before the Christ child, the newborn King of the Jews. ${ }^{93}$ The three magi arrive with a seemingly endless entourage of nobility, who bring along their exotic animals. Adorned in bejeweled regalia, each visitor's magnificent outfit indicates wealth and elite status. Despite this collective affluence, one of the magi kneels at Christ's feet, submitting his immense power to the long-anticipated Savior of the world. We can imagine this crowd of firstcentury one-percenters waiting in line to be blessed by the Almighty God in the flesh.

In my reimagining of the biblical account, the baby Trump, donning a "Make America Great Again" cap, replaces Christ. What once was a bearded magus prostrate before Christ now becomes an Imperial Wizard of the Ku Klux Klan, wrapped in a robe that resembles the Confederate battle flag. He kisses Trump's feet and receives a blessing in return. Instead of the aforementioned gifts, a hooded Klansman brings a bitten apple, while Thomas Jefferson, a slave owner lionized by Trump during the events of Charlottesville, awaits to deliver a McDonald's drive-through order. From a short distance to the right, Robert E. Lee observes atop a white horse Fabriano included in the original composition, which bears a strong resemblance to Lee's horse, Traveller. Below and to Lee's right is Thomas J. "Stonewall" Jackson, Confederate general. To the far left, the first Grand Wizard of the KKK Nathan Bedford Forrest and Melania Trump share a moment and a drink. Above Trump is the conspiracy theorist Alex Jones, ${ }^{94}$ who replaces Joseph in the role of the child's father. Trump counselor Kellyanne Conway, whose icy stare makes direct eye contact with the viewer, plays the part of the Virgin Mary. The remaining arrangement includes vice president Mike Pence, US Senators Lindsey Graham, Mitch McConnell, and Jeff Sessions, US Supreme Court justice Brett Kavanaugh, US secretary of education Betsy DeVos, media executive Steve Bannon, Fox News commentator Sean Hannity, Trump lawyer Rudy Giuliani, Trump political advisors Roger Stone and Stephen Miller, White House Director of Communications Hope Hicks, White House press secretary Sarah Huckabee Sanders, executive vice president of the National Rifle Association Wayne LaPierre, adult actress Stormy Daniels, former Trump associate Jeffrey Epstein, and alt-right favorite Pepe the Frog, united as a sea of conspirators to the most corrupt administration $^{95}$ in recent United States memory.

Finally, above the Trump child is an English translation of the words spoken by Julius Caesar before his crossing of the Rubicon: "Let the die be cast." The crossing inaugurated a five-year civil war, and at its conclusion Julius became emperor of the Roman Empire. Addressing the intensifying polarization and frustration of the US populace, conservative radio host Rush Limbaugh opined: "It cannot go on this way. There cannot be a peaceful coexistence of two completely different theories of life, theories of government, theories of how we manage our affairs. We cannot be in this dire a conflict without something giving somewhere along the way." 96 In making dangerous statements like this (which border on stochastic terrorism), ${ }^{97}$ Limbaugh, Trump, Alex Jones, ${ }^{98}$ and others foment violent sentiment and do little to help deescalate tensions. Although my hope is that the US population avoids bloodshed, the possibility of violent secession appears more plausible than at any time since the US Civil War of the $19^{\text {th }}$ century. 


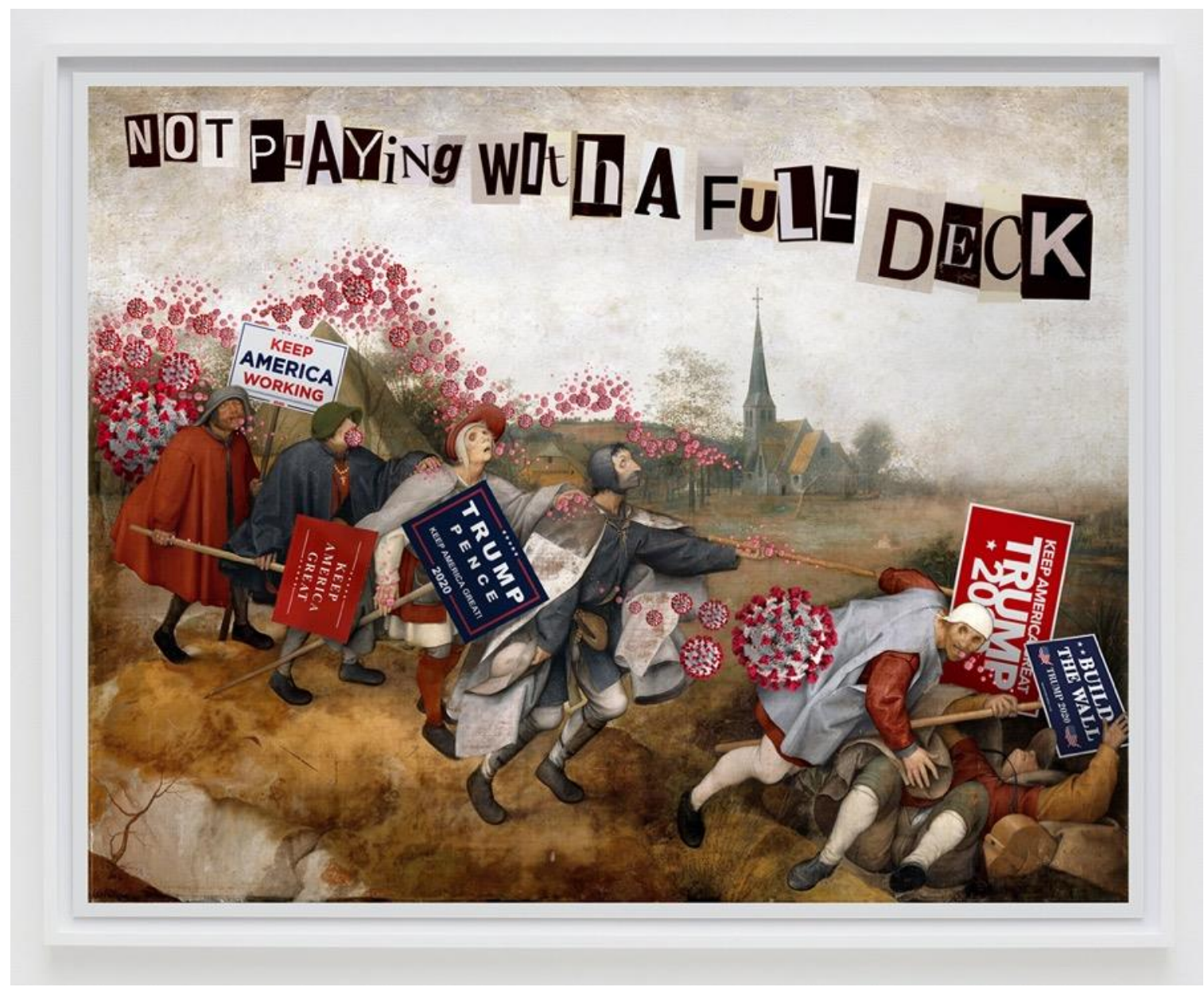

Figure 12. Diran Lyons, Not Playing with a Full Deck: Re-imagining Pieter Bruegel the Elder's The Blind Leading the Blind (1568) (2020). Kodak digital print. Courtesy of the artist.

In April of 2020, I reflected on Trump's response to the COVID-19 pandemic with two collages. One reimagines Pieter Bruegel the Elder's The Blind Leading the Blind (1568), which is an adaptation of Christ's characterization of the Pharisees ${ }^{99}$ as blind guides. ${ }^{100}$ Swarmed by a dense mist of coronavirus germs that trails back to a church in the distance, a procession of blind men advance in single file. They connect arm-to-shoulder for support as they march, but the two at the head of the caravan have just fallen into a ditch. The rest will likely follow. In this frozen moment, the last several parishioners hold up signs with their free hands. These demand that the US economy remain open, defying the Centers for Disease Control and Prevention, which urged the public to practice social distancing. ${ }^{101}$

On March 19, in my home state of California, Governor Gavin Newsom ordered ${ }^{102}$ California's 40 million residents to shelter in place indefinitely. Meanwhile, Trump declared that he wanted the US economy opened by Easter. ${ }^{103}$ I posted ${ }^{104}$ the Bruegel collage on April 11, 2020, the day before 
Easter. I intended to relay a callous admonishment with the piece, but reevaluated the gesture as generous when compared to those willing to sacrifice the weak ${ }^{105}$ for their own revenue streams.

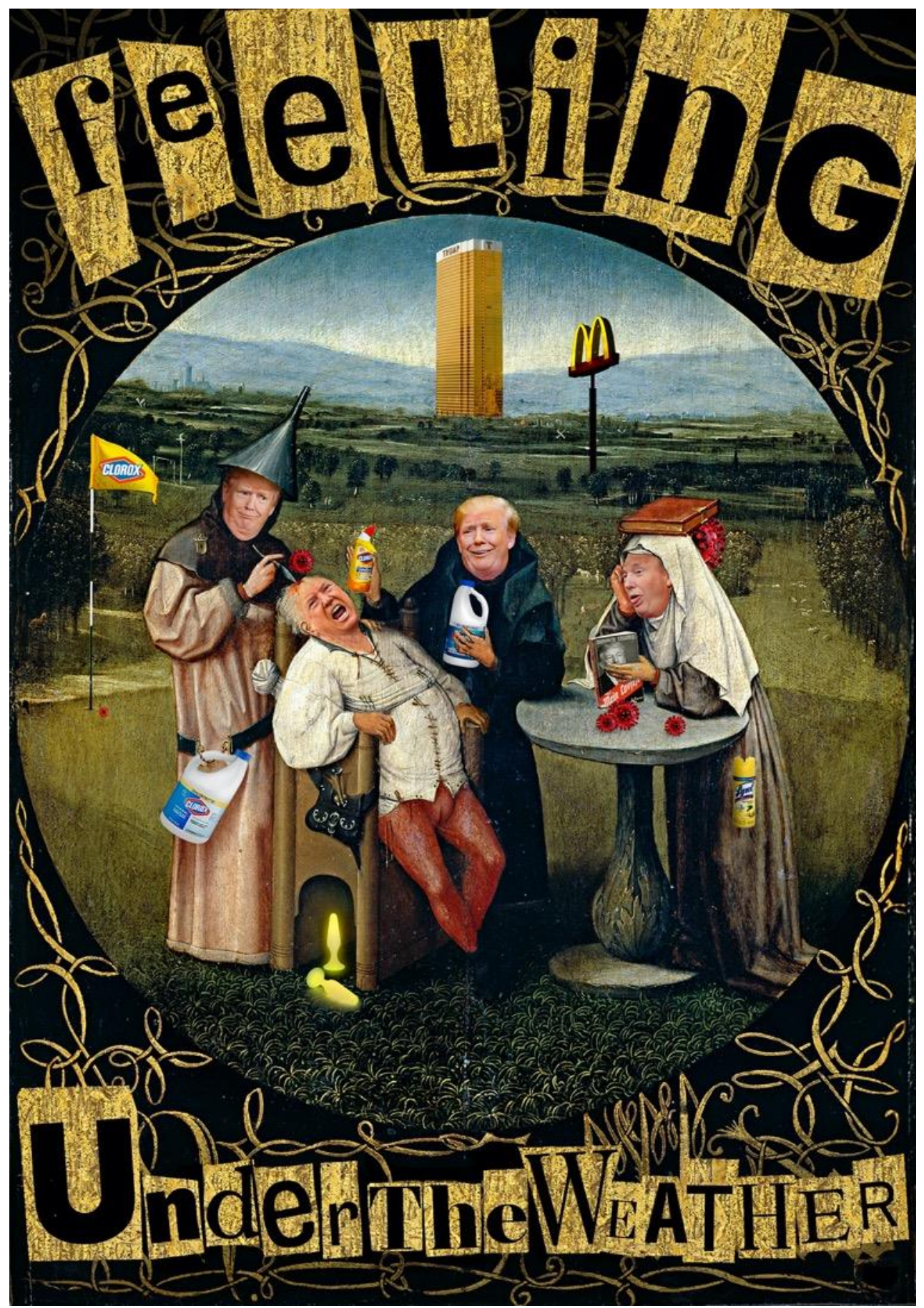

Figure 13. Diran Lyons, Re-imagining Hieronymus Bosch's The Extraction of the Stone of Madness (1494) (2020). Kodak digital print. Courtesy of the artist. 
The second COVID-themed collage appropriates Hieronymus Bosch's The Extraction of the Stone of Madness (1494). In Bosch's day, the stone operation excised the stone of folly from a patient's forehead, curing his stupidity. ${ }^{106}$ In the collage, four figures, each bearing a portrait of Trump, group together around a similar procedure. Instead of the removal of a stone, we see one Trump in the operating chair having coronaviruses released from his head. The Trump to the right of the patient is Trump "the medical genius," 107 raising a container of bleach to pour into the wound. Above his head is a luminous golden Trump Tower in the distance, a glistening skyrise of opulence set within a pastoral landscape. Covering Bosch's beautiful calligraphy is the understated colloquial phrase, "Feeling under the weather," which decorates the periphery of the circular composition. Through such ridicule, I hoped to offer a moment of levity in otherwise exasperating times.

\section{FINAL REMARKS}

In the turbulent year of 2020, Americans faced a collection of crises all at once: the COVID-19 pandemic, economic downturn, police brutality, racial tensions, a humanitarian and refugee crisis at the US southern border, violent protests before ${ }^{108}$ and after $^{109}$ a divisive presidential election, and much more. During this season, I often recalled how the great $19^{\text {th }}$-century polemicist Friedrich Nietzsche grappled with his self-appointed mentor Arthur Schopenhauer's pessimistic view of existence: "Suppose a human being has put his ear to the heart chamber of the world will," Nietzsche wrote. "How would he fail to break?" 110 Beneath this question, Nietzsche's search strives for an affirmation of life, a picture of a life worth living. ${ }^{111}$

I have Jean-François Lyotard in mind in contending that although it may cause considerable discomfort, artists in our troubling times must embrace their roles as voices of disruption, ${ }^{112}$ interrogating those ideological postures and power structures that impede progress and keep certain members of society from flourishing. Through the honest revelation of one's perspectives, challenging discussions can propel us toward the creation of an improved world, or as Nietzsche put it, the world as a work of art. ${ }^{113}$ American art critic and philosopher Arthur Danto championed the artistic excellence of contemporary artists who encourage viewers to recognize injustices where previously they were apathetic or blind to them. ${ }^{114}$ Contemporary artists have done much in this way to contribute to ethical thought and political action, including Mark Bradford, Felix GonzalezTorres, the Guerrilla Girls, Jenny Holzer, Titus Kaphar, Kerry James Marshall, Ana Mendieta, Shirin Neshat, Catherine Opie, Adrian Piper, Lorna Simpson, Rirkrit Tiravanija, Carrie Mae Weems, and Ai Weiwei, to name only a few. As we move into a very uncertain future, climate change, income and gender inequality, systemic racism, sexual violence, and many other matters of injustice demand attention. Those inclined to enlist in this fight can use their creative efforts to help push for a more equitable society that focuses on fortifying the well-being of the collective.

Artists are substantial members of the Fourth Estate and should reject the fear that leads to selfcensorship in the face of increasing intimidation, espouse their perspectives with confidence, and speak against oppressive forces with courage. In so doing, they offer correctives to false pictures of the world, which is a critical first step in actualizing an improved real one. These contributions to discourse provide significant alternatives to regressive voices and the invectives of demagogues, ${ }^{115}$ and so much work remains to be done. The various remix praxes offer contemporary tools to provoke rigorous reflection and dialogue on the very pressing matters of our era. I have found great enjoyment in remix video and now digital collage as rewarding forms of 
communication in the age of social media and rapid information exchange; the challenges are many, but the useful forms for addressing such problems are diverse. Now is an opportune and critical moment to contemplate the role of art with all its diversity in actualizing possible worlds through creative and critical thought.

\section{ACKNOWLEDGEMENTS}

I would like to thank xtine burrough, Owen Gallagher, and Eduardo Navas for the opportunity to contribute to this special issue of Media- $N$. I always appreciate the meticulous feedback I receive when working with such a great team of editors and accomplished writers on remix studies. I am grateful to Porterville College for hosting the first solo exhibition of the Notes and Narratives collage series in November of 2019. The show prompted rewarding dialogue in Tulare County in the Central Valley of California. I am indebted to my Porterville College colleague Jim Entz for the generous insights he shared on the collages. He also had a deep influence on this text. Matthew Potter's suggestions were pivotal to the completion of the images during their production, and I am always thankful to receive his rigorous scrutiny. Ben Makino and Sarah Rector inspired the collage based on Bosch, and the conversation we had at its inception helped clarify the direction of the picture. Finally, I am indebted to Desiree D'Alessandro for her thorough feedback and support. Her presence propelled the completion of this essay.

\section{ENDNOTES}

1. Jorge Luis Borges, Labyrinths: Selected Stories and Other Writings, eds., Donald A. Yates and James E. Irby (New York: New Directions, 1964), 28.

2. Matthew 24:6, Mark 13:7, Luke 21:9.

3. Arthur Schopenhauer, The World as Will and Idea, trans., R.B. Haldane and J. Kemp, Vol. III (London: Kegan Paul, Trench, Trübner \& Co., 1909), 392-93.

4. Jonathan McIntosh, "A History of Subversive Remix Video before YouTube: Thirty Political Video Mashups Made between World War II and 2005," Journal for Transformative Works and Cultures, 2012. Accessed July 3, 2020.

https://journal.transformativeworks.org/index.php/twc/article/view/371/299.

5. Diran Lyons, George W Bush Battles Jesus Christ (2007), YouTube, 8:27, accessed July 3, 2020. https://youtu.be/X7N3Ay5knf0.

6. My spatial productivity slowed, but examples of my sculpture, painting, and installation work during this period are available on my Instagram, https://www.instagram.com/p/B7Ms6PxA7oS/ and on my website, https://www.diranlyons.com/.

7. Michel Paradis, “The Lost Cause's Long Legacy." The Atlantic, June 26, 2020, accessed July 3, 2020.

https://www.theatlantic.com/ideas/archive/2020/06/the-lost-causes-long-legacy/613288/.

8. Robert Horton, “Identity 'Correction' Is the Yes Men's Specialty.” HeraldNet.com, September 30, 2004, accessed July 3, 2020. https://www.heraldnet.com/life/identity-correction-is-the-yesmens-specialty/.

9. Diran Lyons, Bushwhacked II (2003/2013), YouTube, 4:00, accessed July 3, 2020. https://youtu.be/q12_VT9IVg. 
10. Diran Lyons, State of the Union (2014 Political Remix Video), YouTube, 1:45, accessed July 3, 2020. https://youtu.be/0rs_Yic1yoM.

11. Libby Nelson, “'Grab 'Em by the Pussy': How Trump Talked about Women in Private is Horrifying." Vox,

October 07, 2016, accessed July 3, 2020. https://www.vox.com/2016/10/7/13205842/trumpsecret-recording-women.

12. Jeremy Diamond, “Trump: I Could 'Shoot Somebody and I Wouldn't Lose Voters." CNN, January 24, 2016, accessed July 3, 2020. https://www.cnn.com/2016/01/23/politics/donald-trumpshoot-somebody-support/index.html.

13. John Berger, Ways of Seeing (London: Penguin Books, 1990), 26.

14. Ibid.

15. Ways of Seeing, Episode 1, "Ways of Seeing," directed by Michael Dibb, written and performed by John Berger, aired January 8, 1972, on British Broadcasting Corporation (BBC).

16. Eduardo Navas, "Regressive and Reflexive Mashups in Sampling Culture," in Mashup

Cultures, ed. Sonvilla-Weiss (New York: Springer-Verlag/Wien, 2010), 159.

17. Jack Spector, "A Symbolist Antecedent of the Androgynous 'Q' in Duchamp's 'L.H.O.O.Q,"” Notes in the History of Art 18, no. 4 (1999): 40-7, http://www.jstor.org/stable/23206812.

18. Diran Lyons, Jeremiah Wright Painting a Picture of US Aggression (2008), YouTube, 2:00, accessed July 3, 2020. https://youtu.be/MRjR0tP3wzE.

19. Owen Gallagher, Reclaiming Critical Remix Video: The Role of Sampling in Transformative Works (New York: Routledge, 2018), 105-6.

20. Jonathan McIntosh, Building a Critical Culture with Remix Video: A Talk by Jonathan

McIntosh, YouTube, 35:46, accessed July 3, 2020. https://youtu.be/xwpI9yTnuBQ.

21. Jeff Zeleny, "An Angry Obama Renounces Ties to His Ex-Pastor." The New York Times, April 30, 2008, accessed July 3, 2020.

https://www.nytimes.com/2008/04/30/us/politics/30obama.html.

22. Eduardo Navas, Remix Theory: The Aesthetics of Sampling (Vienna and New York: Springer, 2012), 66.

23. Diran Lyons, OBAMA LIKES SPENDING (Project 12, 3/12), YouTube, 6:24, accessed July 3, 2020. https://youtu.be/K-JuE9esfUc.

24. Andy Baio, “The Video Remix 'Supercut' Comes of Age.” Wired, November 11, 2011, accessed July 3, 2020. https://www.wired.com/2011/11/supercut/.

25. Popspot, Welcome Keynote: SUPERCUTS - part 3/4 - ROFLcon 2012, YouTube, 15:20, accessed July 3, 2020. https://youtu.be/aor4ZFScrEE.

26. THR Staff, "Donald Trump Video Showcases His Insults About Mexicans in Three Minutes." The Hollywood Reporter, September 8, 2015, accessed July 3, 2020.

https://www.hollywoodreporter.com/news/donald-trump-mexican-insult-video-820917.

27. Tina Nguyen, "Here's a 3-Minute Supercut of Donald Trump Talking About Mexico." Vanity Fair, September 8, 2015, accessed July 3, 2020.

https://www.vanityfair.com/news/2015/09/donald-trump-mexico-video-supercut.

28. Diran Lyons, Trump Vs Mexico Supercut, YouTube, 3:00, accessed July 3, 2020.

https://youtu.be/WCrWIeb74MI.

29. Eduardo Navas, Owen Gallagher, and xtine burrough, eds., Keywords in Remix Studies (New York: Routledge, 2018), 97.

30. Richard Dyer, Pastiche (New York: Routledge, 2007), 1-8. 
31. Anna Niederlander, "Reversing the Gaze: Manet's 'Olympia' and Titian's 'The Venus of Urbino."” Hasta, October 16, 2019, accessed July 3, 2020. http://www.hasta-

standrews.com/features/https/artsandculturegooglecom/asset/olympia/ywfei4rxgcso1qhlen-gb.

32. The Impressionists, episode 1, "Part 1." Directed by Tim Dunn, Aired April 4, 2006, on

British Broadcasting Corporation (BBC).

33. Diran Lyons, Presidential Debate (Anchorman Remix), YouTube, 1:09, accessed July 3, 2020. https://youtu.be/uiYGdhPIuXQ.

34. Diran Lyons, The 2016 Election Gets Princess Brided, YouTube, 2:39, accessed July 3, 2020. https://youtu.be/FQfiROGdt_c.

35. Chase Stephens, "Video: The 'Princess Bride'-ing of the 2016 Election." The Daily Wire, December 20th, 2016, accessed July 3, 2020. https://www.dailywire.com/news/video-princessbride-ing-2016-election-chase-stephens

36. Dan Amira, "This ' 99 Problems' Obama Remix Is Better Than the Original." New York Magazine, September 28, 2012, accessed July 3, 2020.

https://nymag.com/intelligencer/2012/09/99-problems-obama-video-mitt-jay-z.html.

37. Umberto Eco, A Theory of Semiotics (Bloomington: Indiana UP, 1976), 69.

38. Ferdinand de Saussure, A Course in General Linguistics, trans., Wade Baskin (New York:

McGraw-Hill, 1959), 67.

39. Roland Barthes, Elements of Semiology, trans., Annette Lavers and Colin Smith (New York:

Hill and Wang, 1967), 89-94.

40. Marita Sturken and Lisa Cartwright, Practices of Looking: an Introduction to Visual Culture (New York: Oxford University Press, 2009), 20.

41. Charles Sanders Peirce, "On the Nature of Signs," in Peirce of Signs, ed. James Hoopes (Chapel Hill: The University of North Carolina Press, 1991), 141.

42. Daniel Chandler, Semiotics: The Basics (New York: Routledge, 2002), 142.

43. Christopher Norris, Derrida (Cambridge, Massachusetts: Harvard University Press, 1987), 13. 44. Breazeale, Daniel, "On Truth and Lying in a Nonmoral Sense," in Philosophy and Truth: Selections from Nietzsche's Notebooks of the early 1870s (New Jersey: Humanities Press, 1979), 84. Here, I am referring to Nietzsche's designation of "truth" as a metaphor, an influential idea that serves as a precursor to post-structuralist motivations.

45. Jacques Derrida, Dissemination, trans., with additional notes by Barbara Johnson (Chicago: University Press, 1981), 97.

46. Roman Jakobson notes: "The notion of binaries is essential; without [them] the structure of language would be lost. Where there are two terms in opposition, the two are always present in one's awareness." He asserts it is only through this "dichotomous principle underlying the whole system of distinct features in language" that a conscious human being has awareness of any type. Roman Jakobson, On Language, ed. Linda R. Waugh and Monique Monville-Burston (Cambridge: Harvard University Press, 1995), 321, 490.

47. Christopher Norris, Derrida, 113-14.

48. Jean-François Lyotard, The Postmodern Explained: Correspondence 1982-1985, trans., Barry Don, Bernadette Maher, Julian Pefanis, Virginia Spate, and Morgan Thomas. Afterword by Wlad Godzich (Minneapolis: University of Minnesota Press, 1992), 16.

49. Ludwig Wittgenstein, Philosophical Investigations (New York: Macmillan Publishing Co. 1968), 5.

50. Roland Barthes, Writing Degree Zero, trans., Jonathan Cape (New York: Hill and Wang, 1967), 22-6. 
51. I deeply appreciate Derrida's thoughts on undecidability, Wittgenstein's duck-rabbit, and Kant on the antinomies. These collages attempt to explore the vibration of meaning between oppositions.

52. Diran Lyons, I Cannot Say Enough Good Things About Him (2019). Instagram, October 13, 2019, accessed July 3, 2020. https://www.instagram.com/p/B3jbSeTAyOF/.

53. Diran Lyons, Working on Some Tongue-in-Cheek (False) Affirmations. Instagram, September 28, 2019, accessed July 3, 2020. https://www.instagram.com/p/B29hRwjALNI/. 54. Diran Lyons, \#Impeach \#Donald \#Trump. Instagram, September 25, 2019, accessed July 3, 2020. https://www.instagram.com/p/B21IrxSADy-/.

55. Vida Hull, ARTH 4007 Albrecht Dürer - Part 1, YouTube, 57:45, accessed July 3, 2020. https://youtu.be/65ipZ-tLkKM.

56. Beth Harris and Steven Zucker, Dürer, Self-portrait (1500), YouTube, 3:23, accessed July 3, 2020. https://youtu.be/ZoiY6ZLEKaY.

57. H. W. Janson, History of Art. 5th ed. (Upper Saddle River, NJ: Prentice Hall, 1997), 530.

58. Ibid, 531.

59. Christopher Masters, Renaissance (London: Merrell, 2008), 41.

60. Phillip Adams, "Why Do White Evangelicals Worship at the Altar of Donald Trump?" ABC, Aug 25, 2020, accessed December 3, 2020.

https://www.abc.net.au/radionational/programs/latenightlive/why-white-evangelicals-worship-atthe-altar-of-donald-trump/12566462.

61. Erika Boeckeler, "Painting Writing in Albrecht Dürer's Self-Portrait of 1500," Word \& Image, 28:1, (2012): 43, https://www.tandfonline.com/doi/abs/10.1080/02666286.2011.651262.

62. Military.com. Beretta M9 Pistol. Accessed July 3, 2020.

https://www.military.com/equipment/m9-pistol.

63. Mehdi Hasan, “After El Paso, We Can No Longer Ignore Trump's Role in Inspiring Mass Shootings." The Intercept, August 4, 2019, accessed July 3, 2020.

https://theintercept.com/2019/08/04/el-paso-dayton-mass-shootings-donald-trump/.

64. Nicole Hemmer, "Why It's So Scary When Trump Tweets about Civil War." CNN, October

1, 2020, accessed July 3, 2020. https://www.cnn.com/2019/09/30/opinions/trump-civil-wartweets-make-america-less-safe-hemmer/index.html.

65. Mary B. McCord, "Armed Militias Are Taking Trump's Civil War Tweets Seriously." Lawfare, October 31, 2019, accessed July 3, 2020. https://www.lawfareblog.com/armed-militiasare-taking-trumps-civil-war-tweets-seriously.

66. Oma Seddiq and Jake Lahut, "The Arizona GOP Asks Supporters If They're Willing to Die to Overturn Trump's Election Loss.” Business Insider, December 8, 2020, accessed Dec 8, 2020. https://www.businessinsider.com/arizona-gop-tweet-asks-if-supporters-would-die-overturnelection-2020-12.

67. Ed Pilkington and Sam Levine, “'It's Surreal': US Officials Facing Violent Threats as Trump Claims Voter Fraud." The Guardian, Dec 10, 2020, accessed December 10,

2020. https:/www.theguardian.com/us-news/2020/dec/09/trump-voter-fraud-threats-violencemilitia.

68. Diran Lyons, What If Trump Talked about White Terrorists Like This? YouTube, 4:51, accessed July 3, 2020. https://youtu.be/82_nXGnhoyU.

69. The individuals used five different types of weaponry. In their order of appearance: Mark Anthony Conditt, bombs. James Harris Jackson, sword. James Alex Fields, car. Stephen Paddock, "bump-stock" semi-automatic firearms. Dylann Roof, handgun. 
70. BBC News Staff, "San Bernardino Attack: Obama Vows to Overcome Terror Threat." $B B C$ News, Dec 7, 2015, accessed July 3, 2020. https://www.bbc.com/news/world-us-canada35021210 .

71. Genesis 3.

72. Genesis 3:6.

73. Genesis 3:14.

74. Genesis 2:16-17

75. Roland Barthes, “The Death of the Author," Image, Music, Text, trans., Stephen Heath (New York: Hill and Wang, 1978), 142-8.

76. Dietrich Bonhoeffer, Creation and Fall / Temptation, trans., John C. Fletcher (New York: Macmillan Publishing Company, 1959), 68.

77. Suzanne Gamboa, "Donald Trump Announces Presidential Bid By Trashing Mexico, Mexicans.” NBC News, June 16, 2015, accessed July 3, 2020.

https://www.nbcnews.com/news/latino/donald-trump-announces-presidential-bid-trashingmexico-mexicans-n376521.

78. PBS NewsHour, Watch Presidential Candidate Donald Trump's Full Speech at the 2016 Republican National Convention, YouTube video, 1:15:46, accessed July 3, 2020. https://youtu.be/va9ilyjMyik.

79. NPR Staff, "COVID-19 Briefing: Trump Attacks Media, Says Only He Can Reopen Economy.” NPR, April 14, 2020, accessed July 3, 2020.

https://www.npr.org/2020/04/14/833907848/covid-19-briefing-trump-attacks-media-says-onlyhe-can-reopen-economy.

80. Shane Croucher, "Donald Trump Promised to Eliminate the Deficit in 8 Years. So Far, He Has Increased it by 68\%." Newsweek, Oct 8, 2019, accessed July 3, 2020.

https://www.newsweek.com/trump-deficit-debt-cbo-data-obama-1463802.

81. Tal Kopan, "10 Groups Donald Trump Offended Since Launching His Campaign.” CNN, Nov 29, 2015, accessed July 3, 2020. https://www.cnn.com/2015/11/27/politics/donald-trumpinsults-groups-list/index.html.

82. Roman Jakobson, On Language, 125.

83. Christopher Norris, Derrida, 114.

84. Ibid., 114.

85. John Harwood, “Trump's Coronavirus Mismanagement Again Undercuts His CEO Image." CNN, April 5, 2020, accessed July 3, 2020. https://www.cnn.com/2020/04/05/politics/presidentmanagement-covid-2020/index.html.

86. Centers for Disease Control and Prevention, “CDC COVID Data Tracker.” January 21, 2020, accessed January 1, 2021. https://covid.cdc.gov/covid-data-

tracker/\#cases_casesper100klast7days.

87. Raw Story, Ken Burns: The Civil War was about 'Slavery, Slavery, Slavery', YouTube, 4:21, accessed July 3, 2020. https://youtu.be/T9fswzDbbMc.

88. Diran Lyons, Shelby Foote on the Monuments Men (Praising Confederate Generals),

YouTube, 1:36, accessed July 3, 2020. https://youtu.be/ahZMAHiOhhA.

89. Ta-Nehisi Coates, "What This Cruel War Was Over: The Meaning of the Confederate Flag Is Best Discerned in the Words of Those Who Bore It." The Atlantic, June 22, 2015, accessed July 3, 2020.

https://www.theatlantic.com/politics/archive/2015/06/what-this-cruel-war-was-over/396482/.

90. Wall Street Journal, Full Q\&A: Trump Again Blames Both Sides for Charlottesville Violence, YouTube, 17:00, accessed July 3, 2020. https://youtu.be/IKLKImE5UII.

91. https://twitter.com/ProjectLincoln. 
92. Ed Mazza, "Republican Group Says Trump Just Became the 'Confederacy's Second President."” The Huffington Post, June 11, 2020, accessed July 3, 2020.

https://www.huffpost.com/entry/lincoln-project-confederatetrump_n_5ee1d7adc5b6530fcb96f1ee.

93. Matthew 2:2.

94. Frontline, "Alex Jones and Donald Trump: How the Candidate Echoed the Conspiracy Theorist on the Campaign Trail." PBS, July 28, 2020, accessed December 19, 2020. https://www.pbs.org/wgbh/frontline/article/alex-jones-and-donald-trump-how-the-candidateechoed-the-conspiracy-theorist-on-the-campaign-trail/.

95. Elizabeth Warren (Staff), "Warren Releases New Report: Lawlessness and Disorder: The Corrupt Trump Administration Has Made A Mockery of the Hatch Act." Warren.Senate.Gov, October 29, 2020, accessed December 19, 2020. https://www.warren.senate.gov/newsroom/pressreleases/warren-releases-new-report-lawlessness-and-disorder-the-corrupt-trump-administrationhas-made-a-mockery-of-the-hatch-act.

96. John Bowden, "Rush Limbaugh: US 'Trending Toward Secession." The Hill, Dec 10, 2020, accessed December 10, 2020. https://thehill.com/homenews/media/529609-rush-limbaugh-saysus-trending-toward-seccession.

97. David Packman, Security Experts Warn: Trump Is Promoting Terrorism, YouTube, 4:47, accessed December 19, 2020. https://youtu.be/YGuo9tyJ7tI.

98. David Packman, Calls for Alex Jones Arrest over Vile Biden Threat, YouTube, 6:25, accessed December 19, 2020. https://youtu.be/wczIcvNqAbE.

99. The Jewish religious leadership in the first century.

100. Matthew 15:14, Luke 6:39.

101. Apoorva Mandavilli, "Wondering About Social Distancing?" The New York Times, March 16, 2020, accessed July 3, 2020. https://www.nytimes.com/2020/03/16/smarter-

living/coronavirus-social-distancing.html.

102. Scott Neuman, "California Issues 'Stay At Home' Order as Coronavirus Infections Rise."

NPR, March 20, 2020, accessed July 3, 2020.

https://www.npr.org/2020/03/20/818764136/california-issues-stay-at-home-order-as-coronavirusinfections-rise.

103. Kevin Liptak, Maegan Vazquez, Nick Valencia, and Jim Acosta, "Trump Says He Wants the Country 'Opened Up and Just Raring to Go by Easter,' Despite Health Experts' Warnings."

CNN, March 24, 2020, accessed July 3, 2020. https://www.cnn.com/2020/03/24/politics/trumpeaster-economy-coronavirus/index.html.

104. Diran Lyons, This \#Collage is a \#Reimagining of Pieter Bruegel the Elder's 'The Blind Leading the Blind' (1568). Instagram, April 11, 2020, accessed July 3, 2020.

https://www.instagram.com/p/B-1xvUdg8jR/.

105. Dan Evon, "Was a 'Sacrifice the Weak' Sign Shown at a COVID-19 'ReOpen Tennessee'

Rally?" Snopes, April 24, 2020, accessed July 3, 2020. https:/www.snopes.com/fact-

check/sacrifice-the-weak-sign-real/.

106. Walter Bosing, Hieronymus Bosch: Between Heaven and Hell (London: Thames \& Hudson Ltd) 28.

107. Matt Flegenheimer, “Trump's Disinfectant Remark Raises a Question About the 'Very

Stable Genius."' The New York Times, April 26, 2020, accessed July 3, 2020.

https://www.nytimes.com/2020/04/26/us/politics/trump-disinfectant-coronavirus.html. 
108. Daniel Politi, "Four People Stabbed, One Shot as Pro-Trump Protests Turn Violent." Slate, Dec 13, 2020, accessed December 14, 2020. https://slate.com/news-and-politics/2020/12/peoplestabbed-shot-trump-protests-violent-proud-boys.html.

109. Glenn Harlan Reynolds, "Riots of 2020 have Given the Second Amendment a Boost." USA Today, Oct 8, 2020, accessed December 19, 2020.

https://www.usatoday.com/story/opinion/2020/10/08/riots-2020-have-given-boost-secondamendment-column/5901798002/.

110. Friedrich Nietzsche, The Birth of Tragedy, trans., Walter Kaufman, with The Case of Wagner (New York: Vintage, 1966), 21.

111. Ibid.

112. Simon Milpas, Jean-François Lyotard (New York: Routledge, 2003), 50.

113. Karsten Harries, "The World as a Work of Art." The New York Times, Jan 19, 1986, accessed December 19, 2020. https://www.nytimes.com/1986/01/19/books/the-world-as-a-workof-art.html.

114. Arthur Danto, The Abuse of Beauty: Aesthetics and the Concept of Art (Illinois: Open Court, 2003), 108.

115. Diran Lyons, Trump and the Descent into Dictatorship (Death of Democracy 2020 Remix), YouTube video, 1:54, accessed October 5, 2020. https://youtu.be/flGmNmr6pCU.

\section{REFERENCES}

Adams, Phillip. "Why Do White Evangelicals Worship at the Altar of Donald Trump?" ABC. Aug 25, 2020. https://www.abc.net.au/radionational/programs/latenightlive/why-whiteevangelicals-worship-at-the-altar-of-donald-trump/12566462

Amira, Dan. "This '99 Problems' Obama Remix Is Better Than the Original." New York Magazine. September 28, 2012. https://nymag.com/intelligencer/2012/09/99-problemsobama-video-mitt-jay-z.html.

Baio, Andy. "The Video Remix 'Supercut' Comes of Age.” Wired. November 11, 2011. https://www.wired.com/2011/11/supercut/.

Barthes, Roland. Elements of Semiology. Translated by Annette Lavers and Colin Smith. New York: Hill and Wang, 1967.

"The Death of the Author" in Image, Music, Text. Translated by Stephen Heath. New York: Hill and Wang, 1978.

Writing Degree Zero. Translated by Jonathan Cape (New York: Hill and Wang, 1967).

BBC News, "San Bernardino Attack: Obama Vows to Overcome Terror Threat." BBC News.

Dec 7, 2015. Accessed July 3, 2020. https://www.bbc.com/news/world-us-canada35021210 .

Berger, John. Ways of Seeing (London: Penguin Books, 1990).

Ways of Seeing. Directed by Michael Dibb, performed by John Berger. London: British Broadcasting Corporation (BBC), 1972. TV. 
Bonhoeffer, Dietrich. Creation and Fall / Temptation. Translated by John C. Fletcher. New York: Macmillan Publishing Company, 1959.

Borges, Jorge Luis. Labyrinths: Selected Stories and Other Writings. Edited by Donald A. Yates and James

E. Irby, New York: New Directions, 1964.

Bosing, Walter. Hieronymus Bosch: Between Heaven and Hell. London: Thames \& Hudson Ltd.

Bowden, John. "Rush Limbaugh: US ‘Trending Toward Secession.”” The Hill. Dec 10, 2020. https://thehill.com/homenews/media/529609-rush-limbaugh-says-us-trending-towardseccession.

Breazeale, Daniel. "On Truth and Lying in a Nonmoral Sense" in Philosophy and Truth: Selections from Nietzsche's Notebooks of the Early 1870's. New Jersey: Humanities Press, 1979.

Chandler, Daniel. Semiotics: The Basics. New York: Routledge, 2002.

Coates, Ta-Nehisi. "What This Cruel War Was Over: The Meaning of the Confederate Flag is Best Discerned in the Words of Those Who Bore It.” The Atlantic. June 22, 2015. https://www.theatlantic.com/politics/archive/2015/06/what-this-cruel-war-wasover/396482/.

Croucher, Shane. "Donald Trump Promised to Eliminate the Deficit in 8 Years. So Far, He Has Increased it by 68\%." Newsweek. Oct 8, 2019. https://www.newsweek.com/trump-deficitdebt-cbo-data-obama-1463802.

Danto, Arthur. The Abuse of Beauty: Aesthetics and the Concept of Art. Illinois: Open Court, 2003.

Derrida, Jacques. Dissemination. The University of Chicago Press, 1981.

Diamond, Jeremy. "Trump: I Could 'Shoot Somebody and I Wouldn't Lose Voters."” CNN. January 24, 2016. https://www.cnn.com/2016/01/23/politics/donald-trump-shootsomebody-support/index.html.

Dyer, Richard. Pastiche. New York: Routledge, 2007.

Eco, Umberto. A Theory of Semiotics. Bloomington: Indiana University Press, 1976.

Evon, Dan. "Was a 'Sacrifice the Weak' Sign Shown at a COVID-19 'ReOpen Tennessee' Rally?” Snopes. April 24, 2020. https://www.snopes.com/fact-check/sacrifice-the-weaksign-real/.

Flegenheimer, Matt. “Trump's Disinfectant Remark Raises a Question About the 'Very Stable 
Genius."” The New York Times. April 26, 2020.

https://www.nytimes.com/2020/04/26/us/politics/trump-disinfectant-coronavirus.html.

Frontline. "Alex Jones and Donald Trump: How the Candidate Echoed the Conspiracy Theorist on the Campaign Trail." PBS. July 28, 2020.

https://www.pbs.org/wgbh/frontline/article/alex-jones-and-donald-trump-how-thecandidate-echoed-the-conspiracy-theorist-on-the-campaign-trail/.

Gallagher, Owen. Reclaiming Critical Remix Video: The Role of Sampling in Transformative Works. New York: Routledge, 2018.

Gamboa, Suzanne. "Donald Trump Announces Presidential Bid By Trashing Mexico, Mexicans." NBC News. June 16, 2015. https://www.nbcnews.com/news/latino/donald-trumpannounces-presidential-bid-trashing-mexico-mexicans-n376521.

Harries, Karsten. “The World as a Work of Art.” The New York Times. Jan 19, 1986. https://www.nytimes.com/1986/01/19/books/the-world-as-a-work-of-art.html.

Harris, Beth, and Steven Zucker. Dürer, Self-portrait (1500). YouTube video, 3:23, accessed July 3, 2020. https://youtu.be/ZoiY6ZLEKaY.

Harwood, John. "Trump's Coronavirus Mismanagement Again Undercuts His CEO Image." CNN. April 5, 2020. https://www.cnn.com/2020/04/05/politics/president-managementcovid-2020/index.html.

Hasan, Mehdi. “After El Paso, We Can No Longer Ignore Trump's Role in Inspiring Mass Shootings." The Intercept. August 4, 2019. https://theintercept.com/2019/08/04/el-pasodayton-mass-shootings-donald-trump/.

Hemmer, Nicole. "Why It's So Scary When Trump Tweets about Civil War.” CNN. October 1, 2020. https://www.cnn.com/2019/09/30/opinions/trump-civil-war-tweets-make-americaless-safe-hemmer/index.html.

Horton, Robert. “Identity 'Correction’ Is the Yes Men’s Specialty.” HeraldNet.com. September 30, 2004. https://www.heraldnet.com/life/identity-correction-is-the-yes-mens-specialty/.

Hull, Vida. ARTH 4007 Albrecht Dürer - Part 1.

YouTube video, 57:45, accessed July 3, 2020. https://youtu.be/65ipZ-tLkKM.

Jakobson, Roman. On Language. ed. Linda R Waugh and Monique Monville-Burston. Cambridge: Harvard University Press, 1995.

Janson, H. W. History of Art. $5^{\text {th }}$ ed. Upper Saddle River, NJ: Prentice Hall, 1997.

Kopan, Tal. "10 Groups Donald Trump Offended Since Launching His Campaign.” CNN. Nov 29, 2015. https://www.cnn.com/2015/11/27/politics/donald-trump-insults-groupslist/index.html. 
Liptak, Kevin, Maegan Vazquez, Nick Valencia, and Jim Acosta, "Trump Says He Wants the Country 'Opened Up and Just Raring to Go by Easter,' Despite Health Experts' Warnings.” CNN. March 24, 2020. https://www.cnn.com/2020/03/24/politics/trumpeaster-economy-coronavirus/index.html.

Lyons, Diran. George W. Bush Battles Jesus Christ (2007). YouTube video, 8:27, accessed July 3, 2020. https://youtu.be/X7N3Ay5knf0.

-. Bushwhacked II (2003/2013. YouTube video, 4:00, accessed July 3, 2020. https://youtu.be/q12_VT9IVg.

State of the Union (2014 Political Remix Video). YouTube video, 1:45, accessed July 3, 2020. https://youtu.be/0rs_Yic1yoM.

- Jeremiah Wright Painting a Picture of US Aggression (2008). YouTube video, 2:00, accessed July 3, 2020. https://youtu.be/MRjR0tP3wzE.

. OBAMA LIKES SPENDING (Project 12, 3/12). YouTube video, 6:24, accessed July 3, 2020. https://youtu.be/K-JuE9esfUc.

- Trump Vs Mexico Supercut. YouTube video, 3:00, accessed July 3, 2020.

https://youtu.be/WCrWIeb74MI.

Presidential Debate (Anchorman Remix). YouTube video, 1:09, accessed July 3, 2020. https://youtu.be/uiYGdhPIuXQ.

- The 2016 Election Gets Princess Brided. YouTube video, 2:39, accessed July 3, 2020. https://youtu.be/FQfiROGdt_c.

- I Cannot Say Enough Good Things About Him (2019). Instagram. October 13, 2019. Accessed July 3, 2020. https://www.instagram.com/p/B3jbSeTAyOF/.

. Working on Some Tongue-in-Cheek (False) Affirmations. Instagram. September 28, 2019.

Accessed July 3, 2020. https://www.instagram.com/p/B29hRwjALNI/.

. \#Impeach \#Donald \#Trump. Instagram. September 25, 2019. Accessed July 3, 2020. https://www.instagram.com/p/B21IrxSADy-/.

. What If Trump Talked about White Terrorists Like This? YouTube video, 4:51, accessed July 3, 2020. https://youtu.be/82_nXGnhoyU.

- Shelby Foote On The Monuments Men (Praising Confederate Generals). YouTube video, 1:36, accessed July 3, 2020. https://youtu.be/ahZMAHiOhhA.

—. This \#Collage is a \#Reimagining of Pieter Bruegel the Elder's 'The Blind Leading the 
Blind' (1568). Instagram. April 11, 2020. Accessed July 3, 2020.

https://www.instagram.com/p/B-1xvUdg8jR/.

- Trump and the Descent into Dictatorship (Death of Democracy 2020 Remix). YouTube video, 01:54. Accessed August 9, 2020. https://youtu.be/flGmNmr6pCU.

Lyotard, Jean-François. The Postmodern Explained: Correspondence 1982-1985. Translated by Barry Don, Bernadette Maher, Julian Pefanis, Virginia Spate, and Morgan Thomas. Afterword by Wlad Godzich Minneapolis: University of Minnesota Press, 1992.

Mandavilli, Apoorva. "Wondering About Social Distancing?" The New York Times. March 16, 2020. https://www.nytimes.com/2020/03/16/smarter-living/coronavirus-socialdistancing.html.

Mazza, Ed. "Republican Group Says Trump Just Became The 'Confederacy’s Second President." The Huffington Post. June 11, 2020. https://www.huffpost.com/entry/lincolnproject-confederate-trump_n_5ee1d7adc5b6530fcb96f1ee.

McCord, Mary B. “Armed Militias Are Taking Trump's Civil War Tweets Seriously.” Lawfare. October 31, 2019. https://www.lawfareblog.com/armed-militias-are-taking-trumps-civilwar-tweets-seriously.

McIntosh, Jonathan, "A History of Subversive Remix Video before YouTube: Thirty Political Video Mashups Made between World War II and 2005," Journal for Transformative Works and Cultures (2012). https://journal.transformativeworks.org/index.php/twc/article/view/371/299.

. Building a Critical Culture with Remix Video: A Talk by Jonathan McIntosh, YouTube video, 35:46, accessed July 3, 2020. https://youtu.be/xwpI9yTnuBQ.

Milpas, Simon. Jean-François Lyotard. New York: Routledge, 2003.

Navas, Eduardo. Remix Theory: The Aesthetics of Sampling. Vienna and New York: Springer, 2012.

. "Regressive and Reflexive Mashups in Sampling Culture" in Mashup Cultures, ed. Sonvilla-Weiss, (Vienna and New York: Springer 2010).

Navas, Eduardo, Owen Gallagher, and xtine burrough, eds. Keywords in Remix Studies. New York: Routledge, 2018.

Nelson, Libby. "“Grab 'Em by the Pussy': How Trump Talked about Women in Private is Horrifying." Vox. October 07, 2016. https://www.vox.com/2016/10/7/13205842/trumpsecret-recording-women.

Neuman, Scott. “California Issues 'Stay At Home' Order as Coronavirus Infections Rise.” NPR. March 20, 2020. https://www.npr.org/2020/03/20/818764136/california-issues-stay-athome-order-as-coronavirus-infections-rise. 
Nguyen, Tina. "Here's a 3-Minute Supercut of Donald Trump Talking About Mexico." Vanity Fair. September 8, 2015. https://www.vanityfair.com/news/2015/09/donald-trumpmexico-video-supercut.

Niederlander, Anna. "Reversing the Gaze: Manet's 'Olympia' and Titian's 'The Venus of Urbino." Hasta. October 16, 2019. http://www.hastastandrews.com/ features/https/artsandculturegooglecom/asset/olympia/ywfei4rxgcso1qhlen-gb.

Nietzsche, Friedrich. The Birth of Tragedy. Translated by Walter Kaufman, with The Case of Wagner. New York: Vintage, 1966.

Norris, Christopher. Derrida. Cambridge, MA: Harvard University Press, 1987.

NPR. "COVID-19 Briefing: Trump Attacks Media, Says Only He Can Reopen Economy." NPR. April 14, 2020. https://www.npr.org/2020/04/14/833907848/covid-19-briefing-trumpattacks-media-says-only-he-can-reopen-economy.

Packman, David. Security Experts Warn: Trump is Promoting Terrorism.

YouTube video, 4:47, accessed December 19, 2020. https://youtu.be/YGuo9tyJ7tI.

- Calls for Alex Jones Arrest over Vile Biden Threat.

YouTube video, 6:25, accessed December 19, 2020. https://youtu.be/wczIcvNqAbE.

Paradis, Michel. “The Lost Cause's Long Legacy.” The Atlantic. June 26, 2020.

https://www.theatlantic.com/ideas/archive/2020/06/the-lost-causes-long-legacy/613288/.

PBS NewsHour. Watch Presidential Candidate Donald Trump's Full Speech at the 2016

Republican National Convention. YouTube video, 1:15:46, accessed July 3, 2020. https://youtu.be/va9ilyjMyik.

Peirce, Charles S. "On the Nature of Signs" in Peirce of Signs, ed. James Hoopes.

Chapel Hill: The University of North Carolina Press. 1991.

Pilkington, Ed, and Sam Levine. "II's Surreal': US Officials Facing Violent Threats as Trump Claims Voter Fraud." The Guardian. Dec 10, 2020. https://www.theguardian.com/usnews/2020/dec/09/trump-voter-fraud-threats-violence-militia.

Politi, Daniel. "Four People Stabbed, One Shot as Pro-Trump Protests Turn Violent." Slate. Dec 13, 2020. https://slate.com/news-and-politics/2020/12/people-stabbed-shot-trumpprotests-violent-proud-boys.html

Popspot. Welcome Keynote: SUPERCUTS - part 3/4 - ROFLcon 2012.

YouTube video, 15:20, accessed July 3, 2020. https://youtu.be/aor4ZFScrEE.

Raw Story. Ken Burns: The Civil War Was about 'Slavery, Slavery, Slavery.'

YouTube video, 4:21, accessed July 3, 2020. https://youtu.be/T9fswzDbbMc. 
Reynolds, Glenn Harlan. "Riots of 2020 have Given the Second Amendment a Boost." USA Today. Oct 8, 2020. https://www.usatoday.com/story/opinion/2020/10/08/riots-2020have-given-boost-second-amendment-column/5901798002/

Saussure, Ferdinand de. A Course in General Linguistics. Translated by Wade Baskin. New York, Philosophical Library, 1959.

Schopenhauer, Arthur. The World as Will and Idea, tr. R.B. Haldane and J. Kemp, Vol. III. London: Kegan Paul, Trench, Trübner \& Co., 1909.

Seddiq, Oma, and Jake Lahut, "The Arizona GOP Asks Supporters If They're Willing to Die to Overturn Trump's Election Loss." Business Insider. December 8, 2020. https://www.businessinsider.com/arizona-gop-tweet-asks-if-supporters-would-dieoverturn-election-2020-12.

Spector, Jack. "A Symbolist Antecedent of the Androgynous "Q" in Duchamp's "L.H.O.O.Q."“ Source: Notes in the History of Art 18, no.4 (1999): 40-7. Accessed July 3, 2020. http://www.jstor.org/stable/23206812.

Stephens, Chase. "Video: The 'Princess Bride'-ing of the 2016 Election." The Daily Wire. December 20, 2016. https://www.dailywire.com/news/video-princess-bride-ing-2016election-chase-stephens.

Sturken, Marita, and Lisa Cartwright. Practices of Looking: an Introduction to Visual Culture $2^{\text {nd }}$ ed. New York: Oxford University Press, 2009.

THR Staff, "Donald Trump Video Showcases His Insults About Mexicans in Three Minutes." The Hollywood Reporter. September 8, 2015. https://www.hollywoodreporter.com/news/donald-trump-mexican-insult-video-820917.

Warren, Elizabeth (Staff), "Warren Releases New Report: Lawlessness and Disorder: The Corrupt Trump Administration Has Made A Mockery of the Hatch Act." October 29, 2020. https://www.warren.senate.gov/newsroom/press-releases/warren-releases-newreport-lawlessness-and-disorder-the-corrupt-trump-administration-has-made-a-mockeryof-the-hatch-act.

Wall Street Journal, Full Q\&A: Trump Again Blames Both Sides for Charlottesville Violence. YouTube video, 17:00, accessed July 3, 2020. https://youtu.be/IKLKImE5UII.

Wittgenstein, Ludwig. Philosophical Investigations. New York: Macmillan Publishing Co. 1968. Zeleny, Jeff. "An Angry Obama Renounces Ties to His Ex-Pastor." The New York Times. April 30, 2008. https://www.nytimes.com/2008/04/30/us/politics/30obama.html. 


\section{AUTHOR BIO}

Diran Lyons earned a BA in Painting and Drawing at California State University, Fresno (2000) and an MFA in New Genres and Painting at University of California, Santa Barbara (2004), where he was a Regents Fellow. His multidisciplinary art practice is heavily conceptual, with exacting craft and edgy content, including video and photography, collage and painting, indoor and outdoor installation, performance, and critical writing. 